\title{
La XXVI Legislatura y los trabajadores de la ciudad de México (1912-1913)*
}

John Lear
THE UNIVERSITY OF PUGET SOUND

En este ensayo se abordan los medios por los cuales los trabajadores de la ciudad de México se movilizaron políticamente $-\mathrm{y}$ fueron movilizados- en la etapa maderista de la revolución mexicana, prestando particular atención a su relación con la XXVI Legislatura federal.

S egún el diputado Félix Palavicini, las elecciones parlamentarias de 1912 para la XXVI Legislatura fueron las más libres y democráticas en la historia de México; diversos historiadores han repetido, modificado y ocasionalmente cuestionado esta idea. ${ }^{1}$ La libertad en las elecciones, la representatividad ante el Congreso y su efectividad al proponer reformas

* Traducción de Adriana Sandoval.

${ }^{1}$ Palavicini, Diputados, 1976 , p. x; Cumberland, Mexican, 1952, pp. 248-251 y el punto de vista discrepante de Guerra, "Elecciones", vol. 52, núm. 2, 1992. al sistema autoritario heredado, son criterios por los que se puede juzgar el potencial del fallido experimento maderista en el terreno de la democracia. La naturaleza democrática de las elecciones y del Congreso que surgió de ellas, puede medirse por la participación de los distintos grupos sociales en los procesos electorales y políticos. Si los campesinos fueron el grupo social clave que respondió al llamado de Madero a la revuelta armada y a las vagas promesas de una reforma agraria en el Plan de San Luis Potosí en noviembre de 1911, los trabajadores urbanos constituyeron el 
grupo social más numeroso, entre los que respaldaron su candidatura a la presidencia en la primavera de 1910 , y el que resurgiría de nuevo en los momentos políticos claves, durante las décadas revolucionarias.

En su amplio estudio sobre la revolución mexicana, Alan Knight escribe que

los trabajadores urbanos estuvieron disponibles, listos para la movilización; no fueron, por tanto, víctimas inertes $y$ maleables; por el contrario, con la revolución desplegaron una "tendencia muy marcada a la asociación", tanto política como económicamente. ${ }^{2}$

La cita pone de manifiesto dos dilemas a los que se enfrentaron en sus actividades asociativas durante y después de la revolución. Uno de ellos consistió en decidir si la organización debería darse sólo en el lugar de trabajo y dentro de la comunidad de clase, o bien si debería optarse por una "acción múltiple" que impulsara también el cambio a través de la participación política. Dado que, en ciertos momentos, los trabajadores tanto individual como colectivamente, eligieron la participación política, el segundo dilema fue si proseguir con esa estrategia para que ellos y sus organizaciones pudieran afirmarse como actores autónomos dentro de la escena política, ya fuera a través de manifestaciones cívicas y elecciones democráticas, o bien ofreciéndose como disponibles, como clientes en busca de concesiones de los caudillos políti-

\footnotetext{
${ }^{2}$ Knight, Mexican, 1986, vol. I, p. 405.
}

cos a cambio del apoyo de sus cuerpos, sus corporaciones o sus votos.

Este ensayo es un bosquejo de un estudio más amplio sobre la participación política de los trabajadores de la ciudad de México durante la prime. ra década de la revolución mexicana. En él intentaré rastrear los medios por los que se movilizaron políticamente -y fueron movilizados- estos trabajadores durante la fase maderista de la revolución mexicana, prestando particular atención a su relación con la XXVI Legislatura federal. Exploraré cuatro cuestiones relativas a los trabajadores, sus organizaciones y el Congreso. En primer lugar, ¿cómo respondieron ellos y sus organizaciones a las oportunidades de participación en el proceso electoral, particularmente, durante las elecciones al Congreso en 1912? En segundo, ¿cuáles fueron las relaciones de Ios trabajadores y sus organizaciones con los miembros de la XXVI Legislatura? En tercero, ien qué medida atendió el Congreso sus necesidades? La cuarta -y más tentativa-, ¿cómo afectaron y anticiparon estas experiencias su participación política en el largo plazo, después de la caída de Madero y en el México posrevolucionario? Planteo estas preguntas, primordialmente, dentro del contexto de la XXVI Legislatura federal, electa el 21 de junio de 1912, bajo el presidente Madero, y disuelta luego por el general Victoriano Huerta en octubre de 1913. Tomo como centro de atención a los trabajadores de la ciudad de México, tanto por su número como por la importancia organizativa del movimiento obrero en la capital del país, y por su proximidad 
física con el cuerpo legislativo, que dio lugar a una variedad de interacciones personales.

\section{LOS TRABAJADORES Y LA POLITICA PORFIRIANA}

La participación política de los trabajadores urbanos en el México republicano se remonta a la primera década de la independencia. ${ }^{3}$ Pero la textura de esta participación se estableció con la Constitución de 1857 y la República Restaurada, a medida que se fueron formando las primeras organizaciones independientes (no gremiales), ya de un tamaño y organización considerables y como organizaciones mutualistas; tal es el caso del Gran Círculo de Obreros de México, fundado en $\mathbf{1 8 7 2}$ por artesanos de la ciudad de México. John Womack identifica dos tendencias o estrategias distintas entre las organizaciones laborales de esa época: una social, y otra política. Las preocupaciones de estas sociedades oscilaban periódicamente de la ayuda mutua a la lucha contra los patrones; en esos casos, algunas organizaciones optaron, al menos temporalmente, por una confrontación con los patrones en lucha directa y social, sin intervención de las autoridades. Otras recurrieron a las autoridades políticas, al menos durante algún tiempo, para que mediaran en sus conflictos o fomentaran una legislación que mejorara sus condiciones laborales. Por su parte, los líderes políticos se volvieron hacia los trabajadores urbanos en

${ }^{3}$ Warren, "Will", 1992. busca de apoyo. Por ejemplo, en 1876 el Gran Círculo intervino en la sucesión presidencial para apoyar al presidente Lerdo de Tejada y, después de la escisión en 1877, una facción de esa misma organización colaboró con Porfirio Díaz. ${ }^{4}$

En su estudio sobre los artesanos de la ciudad de México durante la República Restaurada, Carlos Illades sostiene que la debilidad del estatus legal de las organizaciones laborales emanaba de la Constitución de 1857 y del Código Civil, mismos que consideraban a los grupos laborales como asociaciones voluntarias restringidas a las actividades económicas y sociales. Esta debilidad jurídica moldeó, a su vez, la naturaleza de la participación política de los trabajadores. Si bien la mayor parte de las sociedades de ayuda mutua rechazó oficialmente en sus estatutos su participación política, "la dirigencia de las agrupaciones mutualistas cumplió la función de enlazar los espacios civil y político, lo privado con lo público, antes unificados y ocupados por las corporaciones artesanales". Las alianzas políticas permitieron a los líderes obreros, a menudo artesanos, participar regularmente como electores en comicios todavía indirectos y, después de asumir sus puestos, negociar posiciones como candidatos en las planillas encabezadas por facciones o jefes políticos (aun cuando aparentemente ninguna de las planillas ganadoras estu-

\footnotetext{
4éase la excelente discusión de estas dos tendencias organizativas, tanto en lo político como en lo social, en Womack Jr., "Luchas", 1994, pp. 332-336.
} 
vo dominada por los candidatos de la clase trabajadora). Según rllades, "con la colaboración de los dirigentes artesanales se montaba una especie de mecanismo clientelar, que se reforzaba desde la prensa de los trabajadores, llamando a los artesa-nos a votar". En la República Restaurada, esta maquinaria política permitió a los líderes obreros ocupar regularmente cargos en el Ayuntamiento de la ciudad de México. Durante el porfiriato, al menos un intermediario de la clase laboral, el impresor y director de $E l$ Hijo del Trabajo, Francisco de Paula González, logró incluso ocupar un lugar en el Congreso. ${ }^{5}$ Durante la década de 1880 , el presidente y el vicepresidente de la organización laboral modera$\mathrm{da}$, el Congreso Obrero, ocuparon cargos de regidores en el Ayuntamiento de la ciudad de México.

Este patrón parece haber cambiado en la década de 1890 , a medida que se debilitaron las organizaciones laborales, que la máquina política porfiriana se hizo más rígida y que los financieros y el grupo de los Científicos incrementaron su control político. ${ }^{6}$ Para 1903, cuando el Ayuntamiento fue despojado oficialmente de sus propiedades e ingresos y quedó reducido a un mínimo papel asesor en el gobierno de la ciudad, ya no se eligió a miembros de las organizaciones laborales para el Ayuntamiento. ${ }^{7}$ Pero su exclusión de la política urbana y nacional no sería duradera. Con las

\footnotetext{
'Illades, Hacia, 1996, pp. 145-146.

${ }^{6}$ Rodríguez, Experiencia, 1996, cap. 2.

${ }^{7}$ Walker, "Porfirian", 1981, p. 271; AHCM, Regidores, 3891.
}

transformaciones productivas y comunitarias que tuvieron lugar en la ciudad de México a la vuelta del siglo, los conflictos laborales en la capital -como en todo el país-, empezaron a crecer dramáticamente, culminando en las revueltas de Cananea y Río Blanco. En su trato con los trabajadores textiles y los ferrocarrileros, el régimen de Díaz abandonó lo que había sido, esencialmente, una política de laissez faire para optar por otra de activa intervención para solucionar y regular los conflictos entre trabajadores y patrones. ${ }^{8}$

En la ciudad de México, los últimos años del porfiriato fueron testigos de una serie de intentos de reconstrucción de los mecanismos de control y consenso entre ellos, que se habían perdido o soslayado. El más importante estuvo a cargo del gobernador científico Guillermo de Landa y Escandón, quien a partir de 1908 , trató de alejar a los obreros de acciones militantes dentro de su lugar de trabajo y de atraerlos hacia las organizaciones mutualistas, en particular, hacia la Sociedad Mutualista y Moralizadora de Obreros del Distrito Federal promovida por él. Aun cuando no era raro que los grupos mutualistas anteriores buscaran el patrocinio de funcionarios o los nombraran presidentes honorarios, esta sociedad difería de los intentos previos del régimen de Díaz, en que cooptaba facciones de organizaciones ya existentes, tales como el Gran Círculo de Obreros de México

\footnotetext{
${ }^{8}$ Anderson, Outcasts, 1976 , pp. 282-232 y apéndice, pp. 331-338; Womack Jr., "Luchas", 1994, p. 338.
} 
de la década de 1870 y el Gran Círculo de Obreros Libres de 1906, para encaminarlos hacia demandas más moderadas.' La sociedad fue notable porque sus iniciativas y recursos provenían enteramente del gobernador y de su grupo de ayudantes (incluyendo una donación personal de Landa y Escandón de mil pesos), y por su intento de agrupar a todos los trabajadores de la ciudad y del Distrito Federal. ${ }^{10}$ En su primera reunión a fines de 1910, estaba representada en ella la mayor parte de las grandes fábricas de la capital y del Distrito Federal, abarcando a casi cinco mil trabajadores. Landa y Escandón los instó a permanecer sumisos ante sus patrones y superiores, y a trabajar hacia el mejoramiento personal y la enmienda de sus vicios. Estos vicios y debilidades individuales, se argumentaba, era lo que les impedía el acceso a la regeneración y el progreso social tan evidente en el resto de la sociedad porfiriana. ${ }^{11}$

El contexto político que dio lugar a la formación de la Sociedad Mutualista y Moralizadora fue el creciente reto político que representaban, para la reelección de Porfirio Díaz, Francisco I. Madero y el Partido Antirreeleccionista. La elección presidencial de 1910 supuso una oportunidad sin pre-

\footnotetext{
'González, Historia, 1957, pp. 344-351;. Hart, Anarcbism, 1978, pp. 43-60; Walker, "Porfirian", 1981, pp. 261-265; Anderson, Outcasts, 1976, pp. 103-110.

${ }^{10}$ Morgan, "Proletarians", 1994, p. 169; Ávila, "La Sociedad", 1993, pp. 117-154.

${ }^{11}$ El Obrero Mexicano, 10 de junio, 23 de diclembre, 1910,27 de enero, 2 de junio, 1911; Cuestionario de las Asociaciones, AGN, RT, 128:31.
}

cedentes para que los obreros se hicieran escuchar y dejaran sentir su presencia. En la capital, como en otras partes, éstos fueron en ella tanto iniciadores como iniciados, y la consiguiente campaña electoral fue fundamental en cuanto a los patrones de movilización política y económica que los trabajadores seguirían en el curso de la década siguiente.

Los estatutos de la Sociedad Mutualista y Moralizadora prohibían tanto a la sociedad misma como a sus miembros, ocupar puestos políticos. Esta postura, dado el papel de landa en la dirección de la organización, equivalía a establecer el statu quo. Además, el órgano oficial de la sociedad, El Obrero Mexicano, hizo referencias vagas a "agitadores" y a quienes negaban al ciudadano común y corriente el "derecho a reelegir a sus líderes". Al mismo tiempo, el periódico describió con simpatía la visita realizada en febrero por el presidente Díaz a la celebración de la Junta Mutualista del Centenario, patrocinada por Landa y Escandón. Como parte de estas festividades, dos obreras encarcelaron simbólicamente al presidente y a su vicepresidente por el "augusto crimen de haber consolidado la patria... a partir de hoy son prisioneros de la patria y sus energías deben dedicarse a ello". Tanto Díaz como su im. popular vicepresidente, Ramón Corral, juraron entonces aceptar el castigo impuesto por el pueblo. ${ }^{12}$ Para

${ }^{12}$ Para la participación política, véase $E l$ Obrero Mexicano, 3 de junio de 1910. La cena con Díaz está narrada en El Obrero Mexicano, 11 de febrero de 1910. 
fines del porfiriato, los mítines reeleccionistas eran famosos por su limitado apoyo popular y por su completa falta de espontaneidad. Según Moisés González Navarro, la poco entusiasta participación de los trabajadores en un desfile en favor de la reelección de Díaz, custodiados por la policía y las bandas militares, llevó a un turista extranjero a preguntar si, en México, los prisioneros siempre marchaban acompañados de música. ${ }^{13}$

\section{LOS TRABAJADORES Y LAS ELECCIONES MADERISTAS}

¿Cómo fue la respuesta de los trabajadores y de sus organizaciones a las oportunidades que les abrió la revolución de participar en las elecciones? En su análisis de la revolución, Jorge Vera Estañol detecta el surgimiento, a fines del porfiriato, de un "proletariado profesionista", producto de una educación política en desarrollo y de sus crecientes aspiraciones políticas; un grupo social que "buscó para sus ocios mentales... el derivativo político". Madero vio en ellos "al único contingente numeroso con que podía hacer su catequismo el partido de oposición". Según Vera Estañol, el resultado de esta combinación en las diversas elecciones que siguieron, fue "una inmensa explosión demagógica, más que una práctica democrática". ${ }^{14}$

13 "La manifestación obrera", México Nuevo, 26 de abril de 1909; González, Historia, 1957, p. 352 .

${ }^{14}$ Vera, Historia, 1976, pp. 41, 101.
Durante las elecciones presidenciales de 1910, muchos trabajadores de la ciudad de México se congregaron con entusiasmo para apoyar la candidatura de Francisco I. Madero rechazando el paternalismo porfiriano. Como quiera que se la caracterice, su participación para apoyar a Madero surgió como un grito de protesta que se aleja de los esfuerzos orquestados por Landa y Escandón para concitarlos a apoyar el statu quo.

En un mitin del 1 de mayo en favor de Madero, patrocinado por las organizaciones laborales, cinco mil personas, a las que The Mexican Herald se refirió como "los sucios", acudieron a vitorearlo, así como a sus distingidos acompañantes, situados en un balcón de la rica colonia Juárez. ${ }^{15}$ Las fotografías de los mítines maderistas muestran que muchos de los asistentes eran capitalinos humildes y clase trabajadora ${ }^{16}$ Entonces el periódico México Nuevo aplaudió esa manifestación de "los hijos del taller", mientras que The Mexican Herald se burlaba de la participación de "the great unwashed" de las colonias de Santa Julia, La Bolsa y San I.ízaro, las colonias marginadas y perifericas de la ciudad. Uno se pregunta hasta qué punto coincidían los trabajadores con las demandas de los líderes antirreeleccionistas, de clase media, demandas en gran medida abstractas, de de-

15 "Cinco mil manifestantes", Evolución, 8 de mayo de 1910; "Flowing oratory at busting Madero rally", Mexican Herald, 2 de mayo de 1910; "Cinco mil ciudadanos desfilan", México Nuevo, 3 de mayo de 1910. 157

${ }^{16}$ Casasola, Historia, 1960, vol. I, pp. 156 . 


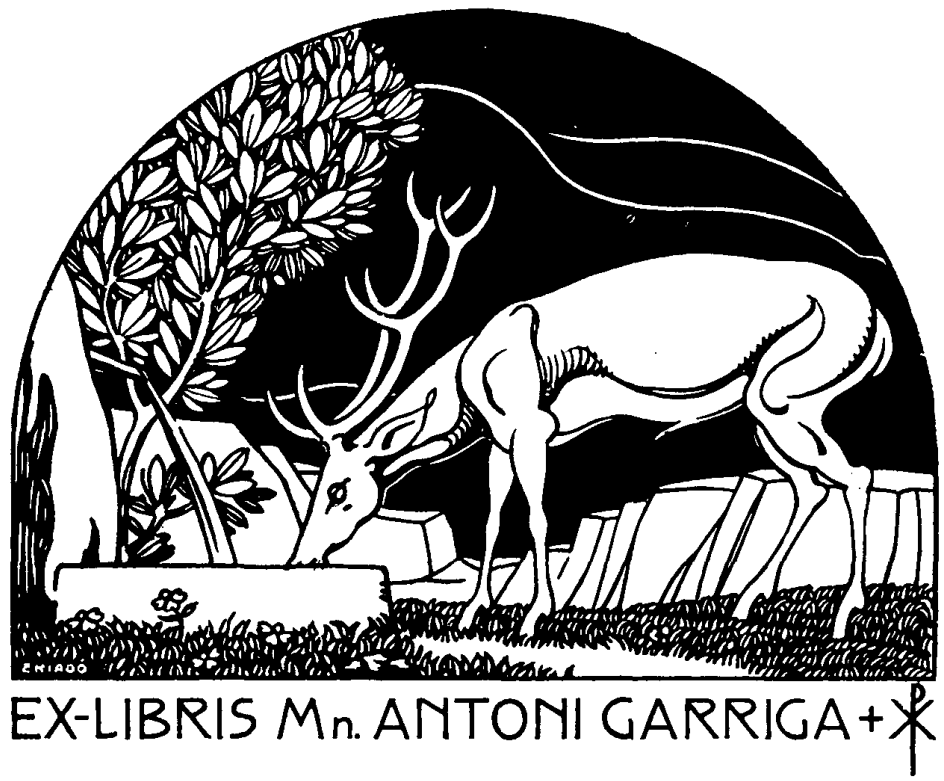

mocracia electoral; o en qué medida aspiraban ellos a concesiones materiales específicas a cambio de su apoyo. ${ }^{17}$ Vera Estañol sintetizó las aspiraciones de los trabajadores que apoyaban a Madero en un verso de una canción popular del periodo:

Poco trabajo, mucho dinero, pulque barato, iViva Madero! ${ }^{18}$

Pero los artículos en los periódicos de los trabajadores de esa época sugieren que al dar su apoyo a Madero en las elecciones, los trabajadores

17 Sobre el apoyo de los trabajadores a Madero, véase Anderson, "Mexican", 1974, pp. 94113, Lear, "Workers", 1993, cap. 4.

${ }^{18}$ Vera, Historia, 1976, p. 226. equiparaban su lucha política en contra de la "tiranía", con sus propias luchas en sus lugares de trabajo y buscaban una auténtica transformación dentro de las relaciones de trabajo y las políticas. ${ }^{19}$ Si bien este discurso había sido identificado antes en una minoría de organizaciones, nunca había llegado a ser tan claramente la cultura política dominante entrc los trabajadores.

Casi un año más tarde, cuando Madero encabezó una revuelta armada y rural en contra de Porfirio Díaz, otras formas de movilización sugieren la

${ }^{19}$ Véase por ejemplo la edición de Evolu. ción, publicada por un grupo de impresores, del 1 de mayo de 1910, que coincidió con el mitin de Madero. 
continuidad de la importancia de los trabajadores de la ciudad de México, tanto en la política local como en la nacional, y asi mismo, el contenido político de la violencia popular urbana, que sería una constante durante la revolución. Las protestas populares urbanas difícilmente iban a quebrantar al régimen porfiriano, militarmente protegido; pero los disturbios de las clases bajas en la ciudad de México, y el temor que despertaron, ayudaron a empujar la transición. El 24 de mayo de 1911, mientras el país aguardaba el anuncio de la renuncia de Díaz, aproximadamente 15000 personas, principalmente de las clases populares, se reunieron espontáneamente frente a la Cámara de Diputados en el centro de México. Por la tarde, cuando quedó claro que Díaz no renunciaría ese mismo día, la multitud tomó brevemente el Congreso antes de marchar hacia el Zócalo gritando "muera el mal gobierno". A medida que se aproximaba la noche, los nerviosos policías dispararon repetidas veces sobre la gente, matando a varios manifestantes e hiriendo a docenas, antes de lograr que la muchedumbre se dispersara. Díaz renunció al día siguiente. ${ }^{20}$

En los días sucesivos, las masas populares que invocaban las libertades democráticas llevaron a cabo una serie de ataques para deponer a los prefectos, jueces y presidentes municipales del Distrito Federal, tildánd los de "despóticos y tiránicos". El propio gobernador, Landa y Escandón, no per-

20 "La gran manifestación popular del viernes", Juan Panadero, 28 de mayo de 1911. dió tiempo y abandonó la ciudad, después de un breve adiós a los miembros de la Sociedad Mutualista y Moralizadora que había fundado. ${ }^{21} \mathrm{Da}$ dos los términos de los Tratados de Ciudad Juárez, que garantizaban un grado sustancial de continuidad a los funcionarios porfiristas en el gobierno posrevolucionario, la violencia popular o su mera posibilidad atraía la represión, aun cuando, en ocasiones, ésta resultara más efectiva para destituir a odiados funcionarios porfirianos que los procedimientos burocráticos o electorales. En el pueblo de Xochimilco, dentro del Distrito Federal, por ejemplo, un grupo de residentes locales logró sacar al presidente municipal del pueblo e instalar uno de su elección. En contraste, 83 hombres en Coyoacán, entonces en las afueras de la ciudad de México, optaron en cambio por solicitar al nuevo gobierno la renuncia de su prefecto y propusieron, sin éxito, a su propio candidato. ${ }^{22}$

La caída de Díaz también revivió claramente el patrón de las organizaciones laborales que había quedado interrumpido un año antes del arresto de Madero, por lo que se iniciaron una serie de huelgas que pondrían a prueba la recién descubierta libertad de los trabajadores, así como la fuerza de su alianza con la nueva elite gobernante. Una de las primeras y ver-

21 "Despedida del Sr. D. Guillermo de Landa y Escandón", El Obrero Mexicano, 2 de junio de 1911.

${ }^{22}$ Los ataques a las juntas populares, todos dentro de las municipalidades del Distrito Federal en las afueras de la ciudad de México, aparecen en AGN, Gobernación 4a: 910-11 (8) (2); 2 (6). 
daderas pruebas de los derechos de los trabajadores, fue la huelga de los tranviarios de junio de 1911, durante el gobierno provisional de Francisco León de la Barra. Más de dos mil operadores de tranvías se fueron a la huelga, luego de que la compañía anglocanadiense rechazara sus demandas de mejores salarios y de poner fin a multas y despidos arbitrarios, entre otras peticiones. La respuesta pública general, dentro de la ciudad, fue inmediata $\mathrm{y}$ de apoyo. Muchas de las organizaciones laborales recién formadas mostraron su solidaridad proporcionando fondos para los huelguistas y marchando en sus manifestaciones, así como enviando mensajes de solidaridad desde todo el país. Algunos funcionarios gubernamentales y miembros de varios partidos políticos y de periódicos recién formados, ofrecieron sus buenos oficios como intermediarios.

El comité de huelga aceptó un trato, negociado por algunos abogados cercanos a Madero, en el cual se consiguió poco más que los huelguistas regresaran sin castigo a sus trabajos. Sin embargo, la mayoría de los tranviarios rechazó tanto el trato establecido, como a su propio comité, y votó por sostener la huelga. La policía, siguiendo órdenes del gobernador del Distrito Federal, atacó a la multitud, hiriendo a varias mujeres y niños y arrestó a más de cien huelguistas, poniendo prácticamente fin a la huelga. El nuevo gobierno, concluyó el periódico $E l$ Radical, había resultado "suavemente tiránico". ${ }^{23}$

${ }^{23}$ Véase la cobertura de la huelga de tranviarios en El Radical, 2, 8, 13 de julio de 1911,
Pero si bien una parte considerable de la organización y de los conflictos labòrales siguieron ocurriendo en el lugar de trabajo, dentro de una atmósfera crecientemente politizada, el primer año después de la caída de Díaz fue también de inquieta espera, entre los trabajadores, por las iniciativas políticas del nuevo gobierno. Las expectativas eran altas entre ellos y las clases populares, pues pensaban que, a través de las elecciones a puestos locales y nacionales, podrían promover a algunos trabajadores $o$, al menos, a representantes progresistas de clase media, que convirtieran los intereses de la gente trabajadora en una prioridad; en esencia, el nuevo orden democrático contribuiría a cerrar la brecha entre la sociedad civil y la política dictada durante el porfiriato.

Los trabajadores se organizaron para ocupar un lugar destacado en las elecciones que siguieron a la caída de Díaz. Los clubes políticos que tenían como centros de operación las fábricas y los barrios fueron revividos o fundados de nueva cuenta. Uno de esos clubes, la Gran Liga Obrera, anunció su intención de "asegurar que los candidatos sean fieles a los trabajadores] y defiendan sus intereses". ${ }^{24}$ Entre estos grupos se encontraban, no sólo los clubes antirreeleccionistas que habían apoyado a Madero en 1910, sino también muchos de los líderes o intermediarios de las organi-

y en Leal y Villaseñor, Clase, 1988, pp. 250 258.

${ }^{24}$ Declaración de La Gran Liga Obrera, formada en julio de 1911, El Radical, 13 de julio 1911. 
zaciones mutualistas que, o bien no estaban de acuerdo en otorgar un papel político a los trabajadores, o bien se habían adherido a la fórmula Díaz-Corral. De la misma manera en que muchos políticos porfiristas lograron sobrevivir sin mella al cambio de regímenes, muchos líderes mutualistas siguieron teniendo nexos muy cercanos con figuras como Landa y Escandón. Pero en general, la campaña de 1910 y la victoria militar de Madero trajeron consigo una nueva generación de líderes laborales a la escena política. ${ }^{25}$

Durante las elecciones presidenciales de octubre de 1911, los trabajadores y sus organizaciones apoyaron en su mayor parte la plataforma de Madero y a su recién creado Partido Constitucional Progresista (PCP), que sustituyó al Partido Antirreeleccionista fundado en 1910. Otros candidatos que buscaron el apoyo laboral, como Francisco León de la Barra y Bernardo Reyes, fueron o bien ignorados o rechazados violentamente por multitudes de trabajadores furiosos. Algunas manifestaciones públicas en contra de los contrincantes de Madero pueden haber sido manipuladas

${ }^{25}$ Como ejemplos podemos citar al ingeniero Carlos Peralta, quien desempeñó un papel clave en la Sociedad Mutualista y Moralizadora del gobernador Guillermo Landa y Escandón, y a Abundio Romo de Vivar; véase $E l$ Radical, 2 de junio de 1911. Peralta se ofreció de hecho en repetidas ocasiones, como intermediario entre el gobierno y la clase trabajadora, bajo los gobiernos de Díaz, Madero, Huerta y de la Convención: véase Araiza, Historia, 1975, t. III,p. 14; AHCM, 404: 755-766, 3841-Regidores; y AGN, periodo Revolución, 130: 48: 2 . por figuras como Gustavo Madero, hermano del candidato, como afirma Vera Estañol; pero muchas otras, como aquellas en contra de la candidatura revivida del general Bernardo Reyes, probablemente reflejaban un rechazo más espontáneo y visceral a una figura que los trabajadores consideraban los había abandonado un año antes. Más que ejercer una violencia arbitraria, ellos repitieron las manifestaciones y las marchas que, bajo la amenaza constante de la represión, habían emprendido un año antes. Muchos trabajadores, incluyendo grupos de impresores, tranviarios y obreros, invirtieron una cantidad considerable de energía en atacar a Reyes o en negar públicamente que lo apoyaban. ${ }^{26}$

Incluso en torno al apoyo a la plataforma maderista, hubo un descontento notable entre algunos grupos que consideraban que las organizaciones e intereses laborales habían sido marginados dentro del partido y quedado fuera del programa y la convención partidarios. Se dieron abundantes quejas entre los trabajaclores en cuanto a la forma en que se deci-

\footnotetext{
${ }^{26}$ Véase la descripción de "la porra" en Vera, Historia, 1976 , p. 219; en torno a los ataques espontáneos al general Reyes y sus partídarios, véase "Gran número de lesionados", Nueva Era, 4 de septiembre de 1911. Para la presencia de los clubes de trabajadores en los mítines maderistas, véase Nueva Era, 20 de agosto de 1911. Para las divisiones y debates entre las organizaciones de trabajadores en torno a Reyes, véanse las declaraciones de los trabajadores en Nueva Era (tranviarios, 4 de septiembre de 1911; empleados libres, 6 de septiembre de 1911; impresores, 15 de septlembre de 1911).
} 
dieron el programa y el candidato a la vicepresidencia y, ciertamente, los intentos por cortejarlos disminuyeron en términos relativos, en comparación con la campaña de $1910 .{ }^{27}$ Numerosos trabajadores desde las filas del Partido Democrático afiliado al maderista, apoyaban la candidatura a la vicepresidencia de Alfredo Robles Domínguez; quien había sido el vínculo maderista clave con las organizaciones populares de la ciudad de México en 1910, por encima del designado por Madero, José María Pino Suáre $z .{ }^{28}$ De manera ostensible, la indiferencia de los líderes del partido maderista se debió a su convicción de que las necesidades de los trabajadores serían satisfechas con la libertad de organizarse como trabajadores y de votar como ciudadanos; pero, probablemente, también reflejaba su confianza en una victoria electoral, su necesidad de apaciguar a algunos elementos de la vieja coalición porfirista gobernante - todavía en el poder -, y tal vez, incluso su temor a las consecuencias de movilizar a los trabajadores y a las clases populares, como quedó de manifiesto en las revueltas del 24 de mayo de 1910, y en la amarga huelga de los tranviarios en junio de 1911.

\footnotetext{
${ }^{27}$ Véase la protesta de Ángel Montalvo en torno a la marginación de los trabajadores en la convención del Partido Constitucional Pro. gresista, "Interesante asamblea en la Gran Liga Obrera", El Obrero Mexicano, 1 de septiembre de 1911 .

${ }^{28}$ Vera, Revolución, 1957, p. 216. Vêanse también los sugerentes comentarios sobre los vínculos entre Robles Domínguez y las organizaciones populares en Rodríguez, "Experiencia", 1996, pp. 271-274.
}

Pese a su marginación política, el entusiasmo de los trabajadores en favor de Madero y del cambio político, quedó demostrado cuando organizaron un gran mitin durante la convención de nominación del PCP en agosto; y también un mes más tarde, cuando los obreros de la fábrica textil Carolina se fueron a la huelga ante la negativa del patrón a darles permiso para enviar una comisión a la estación ferroviaria, a recibir al candidato Madero en su retorno a la capital. ${ }^{29}$ En última instancia, cuando la mayor parte de los mexicanos acudió a las urnas en octubre, había un amplio consenso que congregaba a los trabajadores y a las clases populares en torno a la candidatura de Madero.

Durante las semanas siguientes a la elección presidencial, en las páginas de dos periódicos dirigidos a un público laboral se desarrolló un debate en torno a la participación de los trabajadores en la política nacional. El primero, un periódico "socialista," posiblemente del Partido Socialista Obrero, sugería que era mejor que se mantuvieran alejados de ella para no

servir de juguete de los politicastros y vividores que, cantando hosannas al trabajo, repudian a todos aquellos que llevan sobre sus ropas las manchas de la maquinaria de las fábricas y talleres.

La respuesta vino desde las páginas del periódico El Tipógrafo Mexicano, de mayor circulación:

29 "Colosal manifestación de los obreros y el pueblo", Nueva Era, 28 de agosto de 1911; "Una huelga disuelta por la policía a balazos", Nueva Era, 27 de septiembre de 1911. 
Entre las tinieblas que ya se enroscan a nuestra vieja política de engaños al pueblo, comienzan a brillar, con luz propia, los deseos del pobre[...] E1 obrero[...] ya no será tan fácil presa de los politicastros y vividores. Por el contrario, pronto se separará de ellos al dictado de sus intereses de clase y surgirá, indudablemente, un partido esencialmente obrero que conquiste, con la fuerza incontrastable de su solidaridad, la parte que le corresponde en el tesoro de bienestar social que acumularon las generaciones pasadas. ${ }^{30}$

La ironía de estas dos afirmaciones era que el Partido Socialista Obrero, inspirado en la socialdemocracia alemana, de hecho había defendido la participación de las organizaciones laborales en la política electoral (dentro de su propio partido), mientras que la Confederación de Impresores -que publicaba El Tipógrafo-, de inspiración anarquista, no la aprobaba. Estas dos posturas indican una tendencia creciente, entre algunos trabajadores aún en minoría, hacia la articulación de sus intereses políticos de forma diferente a la de los maderistas liberales de clase media. Eventualmente, la mayor parte de los miembros de ambas organizaciones se encontraría más tarde en las filas de la Casa del Obrero Mundial, de corte anarquista.

Una de las áreas más viables para una participación política de parte de los trabajadores, la de la política municipal, resultó decepcionante. Duran-

${ }^{30}$ Liebknecht, "El obrero debe laborar para triunfar". Reimpreso de El Tipógrafo Mexicano en Nueva Era, 11 de noviembre de 1911. te los meses posteriores a la caída de Díaz, el Ayuntamiento permaneció en manos de los científicos porfirianos, y siguió constreñido su alcance por severas restricciones, como lo había estado desde que sus recursos y autoridad habían sido menguados por Díaz en 1903. Pese a las repetidas manifestaciones públicas frente al edificio del Ayuntamiento para exigir su renuncia, el presidente municipal Francisco Pimentel y Fagoaga, quien había ocupado el puesto durante largo tiempo, se negó a entregarlo, abandonándolo sólo cuando se unió a otros científicos para formar parte del gabinete maderista. ${ }^{31}$

Las elecciones municipales que tuvieron lugar en diciembre de 1911, suscitaron escasa participación popular y dieron como resultado una representación laboral nula. Los problemas en la estructura de las elecciones municipales también socavaron la participación popular. El Ayuntamiento de científicos controló el registro de votantes, así como la selección de los supervisores de casilla. El PCP y otros partidos acusaron repetidamente al recién formado Partido Católico, que había incorporado a numerosos consejeros científicos prominentes y designado funcionarios, de preparar un fraude. ${ }^{32}$ Se dio un obstáculo adicional debido a que las elecciones fueron indirectas: Ios hombres empadronados votaban por un elector de

\footnotetext{
${ }^{31}$ Nueva Era, septiembre-octubre, 1911.

${ }^{32}$ Los ataques tenían como objetivo específico, el secretario del Ayuntamiento de las dos décadas anteriores, Juan Bribiesca, Nueva Era, 5 de diciembre de 1911.
} 
su sección o barrio y luego, esos aproximadamente mil electores, se reunían para elegir a los consejeros que representarían a cada uno de los diez distritos, donde se renovaba la mitad de los veinte cargos en cada elección bianual. En diciembre de 1911, el PCP ganó más de la mitad de los electores; el Partido Católico obtuvo una tercera parte, y el Partido Liberal y otros partidos menores, el resto. La mayoría obtenida por el PCP le permitió imponer a sus candidatos a lo largo de la ciudad, dejando así fuera de los cargos a los partidos con tendencias más hacia su derecha o su izquierda. A diferencia de las décadas de 1870 y 1880 , los líderes de la clase trabajadora no lograron negociar su ingreso como electores dentro de las planillas del PCP, que fueron ocupadas primordialmente por profesionistas conocidos $y$ líderes de partidos, como Serapio Rendón o el ex magonista Antonio Villarreal, quien para ese momento había alejado en gran medida su apoyo previo a las disposiciones radicales $\mathrm{y}$ favorables a los trabajadores, del programa de 1906 del Partido Liberal Mexicano. ${ }^{33}$ Un candidato de los trabajadores podía aspirar, dentro de un partido bien organizado, a ganar el voto de la mayoría en un solo distrito (como en los de mayoría trabajadora: el primero, el segundo y el cuarto), pero tenía pocas oportunidades de ganar el voto de los electores en toda la ciudad.

\footnotetext{
${ }^{33}$ Nueva Era, 3, 4 y 6 de diciembre de 1911. Para el cambio hacia un conservadurismo de parte de Villarreal y otros antiguos miembros del PLM, véase Cockroft, Intellectual, 1968, cap. 8 .
}

Pese al triunfo del PCP en las nuevas elecciones a consejeros, dado que sólo se renovó la mitad de los cargos, los porfiristas mantuvieron el control del poder en el Ayuntamiento y lograron incluso elegir a uno de sus hombres, Pedro Lascuráin, como nuevo presidente municipal, una vez que quedó establecido el nuevo. La autonomía municipal había sido un punto importante para la revolución maderista, pero Madero no había logrado restaurarla con suficiente rapidez, aun cuando, como reconoció el Ayuntamiento de la ciudad de México, ésta siguió siendo un objetivo clave de todas las clases. Si bien este Ayuntamiento incrementó con optimismo y en medida considerable el número de casillas para la elección, muy por encima de los niveles porfiristas, ${ }^{34}$ los votantes fueron apabullantemente escasos. El periódico del PCP, Nueva Era, consideró "que las elecciones para consejeros no habían despertado el debido interés en la opinión pública, debido a que se sabe que nuestro Ayuntamiento difícilmente ha tenido[...] función alguna y ha sido puramente decorativo". ${ }^{35}$

Debido a las circunstancias de la revolución, la de diciembre de 1911 fue la última elección democrática a un ayuntamiento en siete años. Pocos meses después del asesinato de Madero, prácticamente todos los consejeros del PCP habían renunciado,

${ }^{34}$ Rodríguez, Experiencia, 1996, p. 53.

35 "Fue instalado ayer el nuevo Ayuntamiento", Nueva Era, 2 de enero de 1912; "A propósito de las elecciones municipales", Nueva Era, 16 de diciembre de 1911. 


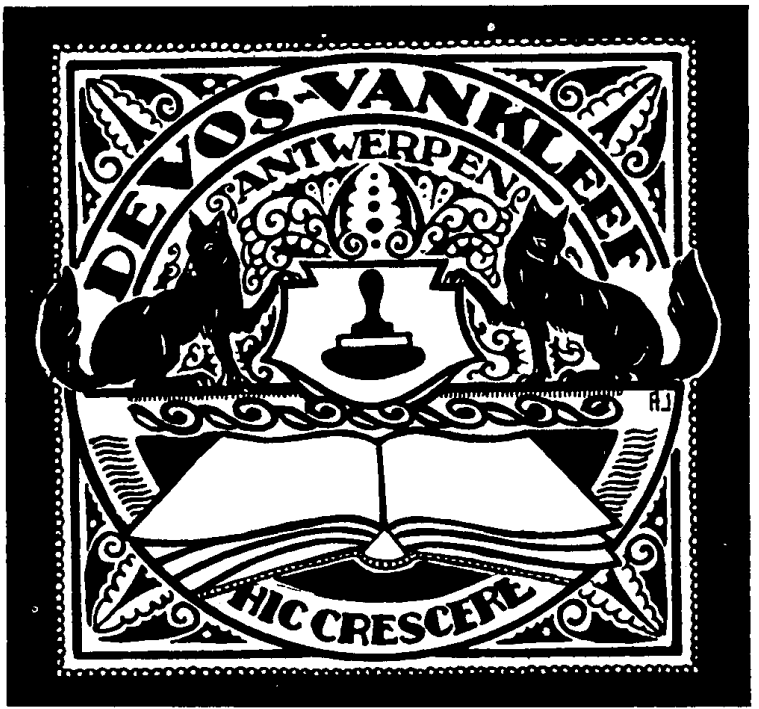

dejando mano libre al general Huerta para orquestar las siguientes elecciones municipales al estilo porfirista, en diciembre de 1913. De esas elecciones, que no lograron convocar ni siquiera a la mitad del número normal de electores, surgió un Ayuntamiento compuesto primordialmente por antiguos consejeros porfiristas. En contraste con el consejo electo de 1911, desprovisto de cualquier tipo de representación por parte de los trabajadores, el consejo huertista in. cluyó al perenne interlocutor de la clase trabajadora, el ingeniero Carlos Peralta y, como alternativa, al autodenominado "trabajador" Ángel Montalvo -los dos habían desempeñado papeles importantes en organizaciones laborales porfiristas. ${ }^{36}$ Finalmen- te, en diciembre de 1917 tuvieron lugar elecciones al Ayuntamiento de la ciudad de México, brevemente restaurado a su estatus de municipio libre, mucho después de que el gobierno municipal había sido reimplantado en la mayor parte del país. ${ }^{37}$

${ }^{36}$ AHCM, 404: 755-766, 3841-Regidores; México Patria, 22 de diciembre de 1913.

${ }^{37}$ Después de que Huerta fue destituido del poder en julio de 1914 , los generales constitucionalistas ocuparon la ciudad y de inmediato reinstalaron a los consejeros electos en 1911 (utilizando a los suplentes en la misma elección para cubrir los cargos adicionales), y en diciembre, justo antes de abandonar la ciudad, decretaron la restauración de la autonomía del Ayuntamiento, tal y como había existido en 1903, una medida sostenida e instrumentada 
La participación popular en los comicios fue alentada por una ley aprobada por las cámaras porfiristas a principios de 1912, que permitía que las elecciones al Congreso se llevaran a cabo por votación directa. Durante la votación de junio de 1912 al Congreso, el Partido Constitucional Progresista oficial llevó a cabo un esfuerzo concertado para incluir a los trabajadores en sus actividades e invitarlos a votar por sus candidatos. Pero estos esfuerzos no lograron incluir demandas laborales específicas en sus programas partidarios ni proponer candidatos en el Distrito Federal vinculados directamente con los clubes políticos de aquéllos. Temeroso de la fuerza del Partido Católico en la capital, el PCP y sus aliados del Partido Liberal intentaron asegurar la mayoría de los doce cargos electorales del Distrito Federal, lo cual condujo a alianzas extrañas $\mathrm{e}$

por la fuerzas opositoras de la Convención. Desde luego, los poderes restaurados del gobierno municipal no llegaron a formalizarse mientras la ciudad estuvo ocupada por los ejércitos revolucionarios y no se podía elaborar un nuevo orden constitucional ni una nueva estructuración fiscal; por otra parte, el Ayuntamiento restaurado de 1915 proporcionó una de las escasas continuidades institucionales que se dieron en el curso de los siguientes ocho meses, a medida que las fuerzas de la Convención y las constitucionalistas tomaban y abandonaban alternadamente la ciudad. Cuando, finalmente, fue tomada definitivamente por las fuerzas constitucionalistas en agosto de 1915, el general Carranza optó por sustituir el Ayuntamiento (que había sido previamente disuelto por los zapatistas durante los cambios de la semana anterior) por un funcionario militar. "La suspensión de los ediles", El Renovador, 24 de julio de 1915. insostenibles con los férreos conservadores del régimen porfirista. ${ }^{38}$

Varios partidos y algunos clubes políticos con bases en los distritos electorales de la capital, propusicron candidatos que eran trabajadores o que tenían claramente una plataforma orientada hacia ellos, dentro o en contra del partido oficial ${ }^{39}$ En los márgenes de los principales partidos existían algunos otros, como el Partido Socialista Obrero fundado en agosto de 1911, poco después de la elección de Madero, por el afinador de pianos alemán Paul Zierold. Si bien nunca logró reunir a más de una cincuentena de miembros ni llegar a ser una fuerza electoral seria, el Partido Socialista Obrero desempeñó un papel importante en la introducción en México de las ideas socialistas europeas e interesó intelectualmente a un grupo efímero de trabajadores calificados en la ciudad de México, que pronto jugaría un papel formativo en el movimiento obrero. ${ }^{40}$

${ }^{38}$ La Fuerza Obrera, 31 de mayo de 1912; Guerra, "Elecciones", 1990, p. 264.

${ }^{39}$ Véanse, por ejemplo, las referencias a los trabajadores y las firmas de los mismos en la declaración "El Partido Constitucional Progresista está en pie", Nueva Era, 24 de abril de 1912, p. 3; "Club Francisco Ferrer Guardia", Nueva Era, 25 de abril de 1912.

${ }^{40}$ Entre quienes participaron brevemente en el Partido Socialista Obrero se encontralua el metalúrgico Jacinto Huitrón, el sastre Luis Méndez y el carpintero Pioquinto Roldán. E1 grupo mantuvo una estrecha correspondencia con los partidos socialistas de los Estados Unidos y de Alemania, y en su periódico El Socialista, así como en las hospitalarias páginas de El Paladín, desde donde defendieron ideas inconcebibles e inaceptables para la mayor 
Algunos pequeños clubes políticos laborales, como el Club Político de Obreros, se registraron de manera separada en el Ayuntamiento, pero como "parte integrante del Partido Constitucional Progresista". ${ }^{41}$ Numerosos trabajadores se unieron al Partido Popular Obrero (PPO) cuando éste fue fundado, justo un mes antes de las elecciones al Congreso. El PPO congregó a muchos de los miembros de las organizaciones mutualistas pro maderistas de la capital y llegó hasta a lanzar candidatos para senador y a seis de los doce diputados por el Distrito Federal; ${ }^{42}$ pero estuvo dominado por el ministro de Gobernación maderista, Jesús Flores Magón y, con excepción de su programa que era abiertamente político, parece haber encajado en gran medida en el molde de las políticas laborales clientelistas ante. riores. $^{\text {43 }}$

Estos partidos se enfrentaron a obstáculos significativos en distintos momentos del proceso electoral, incluso para inscribir los nombres de

parte de los radicales mexicanos, incluyendo a los del PLM, como el sufragio femenino. Araiza, Historia, 1975, t. III, pp. 12-13; Carr, "Marxism", 1983, pp. 282-284. Véanse las denuncias contra este partido de parte de Rafael Pérez Taylor, Nueva Era, 26 de febrero de 1912.

${ }^{41}$ AHCD, Elecciones de Poderes Federales, 877, exp. 80.

${ }^{42}$ Los candidatos del PPO incluían al ingeniero Ezequiel Pérez, quien brevemente había intentado jugar un papel como intermediario en una huelga textil que abarcó a toda la ciudad, el pasado enero. Araiza, Historia, 1975, pp. 12-14; los candidatos aparecen listados en el Mexican Herald, 30 de junio de 1912.

${ }^{43}$ Araiza, Historia, 1975, t. III, p. 38. sus candidatos en las boletas electorales. El PPO, por ejemplo, que propuso candidatos sólo para la mitad de las doce curules, tenía que suscribir 68000 boletas ${ }^{44}$ La confusión creada por este sistema de boletas separadas para cada candidato, propició también acusaciones de fraude, dado que los votantes analfabetos o heterogéneos podían ser manipulados fácilmente, no dándoles todas las boletas necesarias. ${ }^{45}$

El Partido Liberal (PL), que surgió en agosto de 1911, tuvo una mayor importancia electoral. Fue fundado por antiguos miembros del Partido Liberal Mexicano, como Juan Sarabia, Antonio Díaz Soto y Gama y Jesús Flores Magón. El PL fue esencialmente una amalgama de clubes de todo el país, muchos de ellos ligados con personalidades, distritos y sectores sociales, y todos con alianzas independientes y en cierta medida críticas, con Madero y su partido oficial, el Partido Constitucional Progresista. Enraizado en el PIM y su programa de 1906, el Partido Liberal resultó un defensor mucho más articulado de la legislación laboral que el PCP, puesto que incluía en su programa una jornada laboral de ocho horas para los empleados gubernamentales y proponía el fin de los salarios preferenciales para los extranjeros. ${ }^{46}$ Pero de la misma manera en que oscilaba en-

${ }^{14}$ AHCD, Elecciones de Poderes Federales, 877, exp. 81.

is Vera, Revolución, 1957, pp. 246-247

46 "El Partido Liberal pedirá ocho horas de labor como máximum", Nueva Era, 27 de noviembre de 1911. 
tre el apoyo crítico y la oposición al gobierno maderista durante su breve periodo presidencial, el Partido Liberal fluctuó en cuanto al apoyo dado a los trabajadores en los conflictos laborales. En septiembre de 1911, por ejemplo, muchos de los radicales claves dentro del Partido Liberal, antiguos miembros del PLM, retiraron su llamado a una manifestación pública para condenar la represión guberna. mental de los tranviarios en huelga. En su estudio de estos "precursores intelectuales" de la revolución, James D. Cockroft sugiere que, en la época de las elecciones al Congreso, "el PL moderado estaba en peligro de dejar de ser una oposición no violenta, de izquierda, a Madero y sus representantes, y ceder su lugar a los representantes del creciente movimiento laboral" en la ciudad de México. ${ }^{47}$

El ala radical del Partido Liberal ya estaba marginada para la convención del mismo en abril y, con el tiempo, propuso incluso a sus propios candidatos en varios distritos del Distrito Federal, pero la mayor parte del Partido Liberal apoyó a candidatos compartidos con el Partido Constitucional Progresista.

Un ejemplo de los esfuerzos de los radicales fue la candidatura independiente de Felipe Santibáñez en un distrito primordialmente laboral -el segundo- de la ciudad de México. Santibáñez era un abogado, ex miembro del PLM y uno de los fundadores del Partido Socialista Obrero, que contaba con el apoyo de Díaz Soto y Ga-

${ }^{47}$ Cockroft, Intellectual, 1968, p. 202. ma, Juan Sarabia y del Grupo Avanzado del Partido Liberal. Dentro del Partido Liberal, él había diseñado gran parte de la postura del partido en torno a la cuestión agraria y concitó el apoyo laboral a través de su Club Obrero Liberal y de su efímero periódico, Fuerza Obrera. Pero como sucedió con la mayoría de los liberales radicales, tenía antecedentes clasemedieros y tal vez, como corresponde a la estructura y a la crisis social que enfrentaba el país, su principal preocupación era la reforma agraria. De hecho, bajo el destacado liderazgo de Antonio Díaz Soto y Gama, el ala radical de los liberales había planteado repetidas veces la necesidad de una reforma agraria elusiva de los problemas caros a los trabajadores urbanos, y había moderado las demandas laborales planteadas anteriormente en el programa de 1906 del PLM, al igual que en el programa de Tacubaya. Este enfoque contribuyó a debilitar las escasas posibilidades políticas de una alianza electoral entre los radicales de clase media y los trabajadores de la capital. ${ }^{48}$

La participación de los trabajadores en las elecciones al Congreso, se dio con mayor frecuencia a través de un estilo político de tipo "mutualista", como el que tuvo lugar en el décimo distrito electoral del Distrito Federal, en el suburbano pueblo de Tacubaya, donde el ala derecha del

${ }^{48}$ AHCM, Partidos Políticos, 1300: 23; Cockroft, Intellectual, 1968, p. 221; "El Grupo Avanzado de El Partido Liberal y el Club Obrero Liberal 'Unión, Trabajo y Justicià', postulan ...", La Fuerza Obrera, 31 de mayo de 1912. 


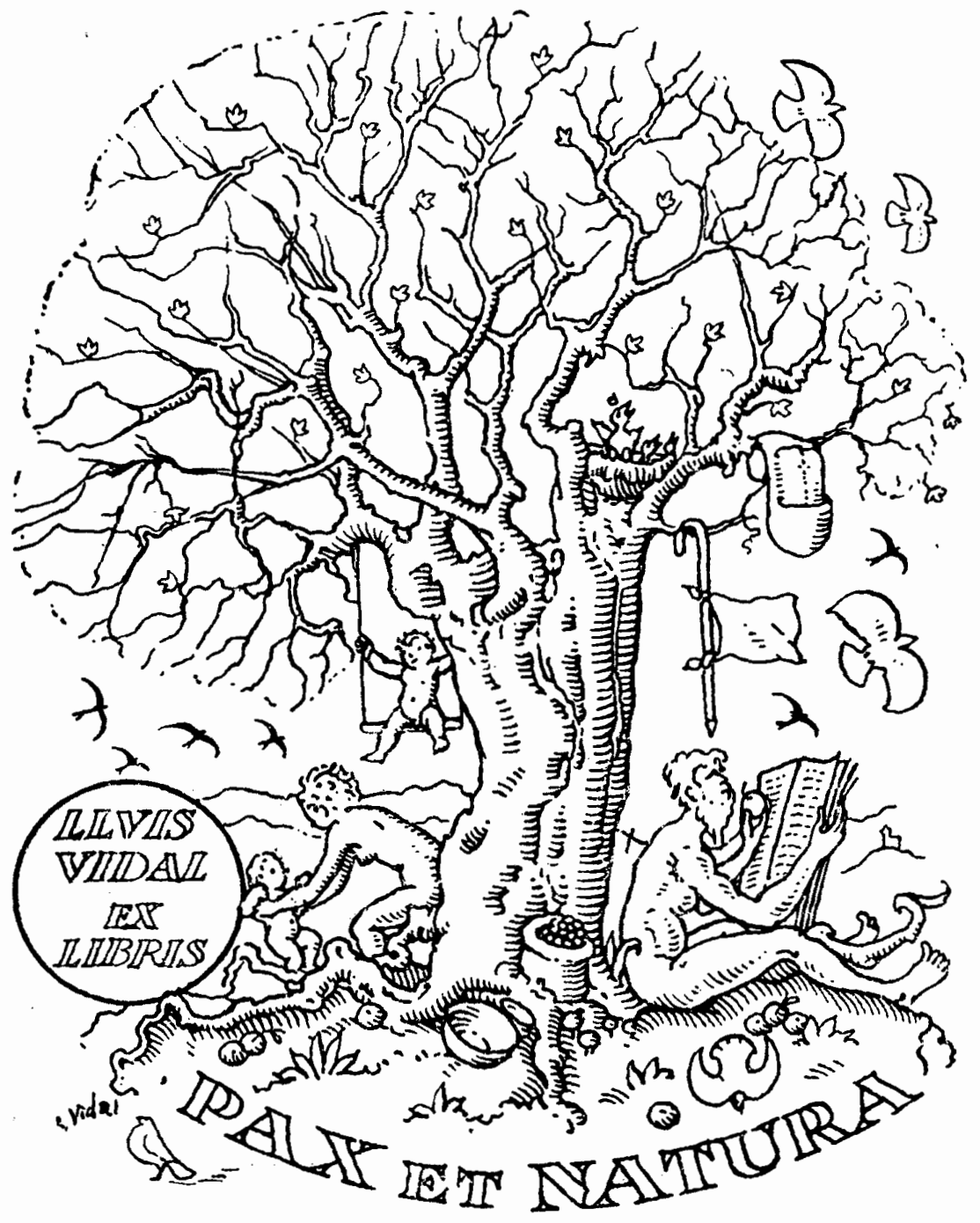


Partido Liberal postuló como candidato al industrial Carlos Zetina. Zetina era un importante financiero, dueño de una gran fábrica de zapatos en Tacubaya, y había representado a los industriales en la convención textil que turo lugar durante el mismo verano que las elecciones. En un auténtico estilo porfirista, Zetina se presentó como un candidato, no de los trabajadores, sino para los trabajadores, y su programa era una extensión del paternalismo filantrópico del gobernador porfirista del Distrito $\mathrm{Fe}$ deral, Guillermo Landa y Escandón. ${ }^{49}$ Con el apoyo del liderazgo del partido y sin duda de muchos de los trabajadores -al menos los de su propia fábrica-, Zetina obtuvo el cargo de diputado por el décimo distrito, mientras que Santibáñez experimentó una amarga derrota en el segundo. Meses después, desde su curul en el Congreso, Zetina encabezó la oposición a una propuesta que favorecía la regulación de las horas y de los salarios en las fabricas textiles. ${ }^{50}$

Lo más cercano a una victoria de un candidato de los trabajadores fue la elección como suplente, en el sexto distrito, del periodista Rafael Pérez Taylor, de la planilla oficial del PCP. Pérez Taylor mantenía vínculos estrechos con las organizaciones laborales y jugaría un papel importante, primero en la organización de los trabajadores dentro de la Casa del Obre-

49 Sobre el llamado de Zetina a los trabajadores, véase "La voz del obrero", El Ideal Democrático, 31 de mayo de 1912.

${ }^{50}$ Ramírez Plancarte, Revolución, 1952, p. 264. ro, y más tarde como defensor de sus derechos en la Convención. Pero como suplente, no tuvo papel alguno en la XXVI Legislatura. En su mayor parte, los trabajadores de la ciudad de México quedaron excluidos de la arena política en esas elecciones y, para llegar a contar con alguna representación en el Congreso e influencia en el proceso legislativo, tuvieron que depender de un puñado de líderes radicales clasemedieros, electos al Congreso por otros estados, como Heriberto Jara y Juan Sarabia. ${ }^{51}$ En la tribuna del Congreso, Heriberto Jara presumía de sus raíces proletarias, pero en realidad, había nacido en una familia de clase media y había sido contador en la fábrica de Río Blanco, participando en la huelga de ese lugar; de hecho, fue electo con el apoyo de los trabajadores textiles de Orizaba. ${ }^{52}$ José Natividad Macías, abogado, se preciaba de haber sido electo por los mineros de su natal Guanajuato. ${ }^{53}$

Justo antes de las elecciones al Congreso, el periódico Fuerza Obrera, que apoyaba la candidatura de Santibáñez para el segundo distrito de la ciudad de México, lamentó los efectos de "la larga abstinencia política de la inmensa mayoría del pueblo mexicano" bajo una larga dictadura. ${ }^{54} \mathrm{La}$ par-

${ }^{51}$ Camp, Mexican, 1991, p. 351.

52 Ibid, 1991, y Ramírez Plancarte, Revolución, 1952, p. 481, "Mi familia pertenecía a la clase media de la ciudad (Orizaba); mi padre tenía una fábrica de ruedas de carreta". Zapata, Conversaciones, s.a., p. 19.

${ }^{33}$ Ramírez Plancarte, Revolución, 1952, p. 48.

${ }^{54}$ La Fuerza Obrera, 31 de mayo de 1912. 
ticipación nacional en las elecciones al Congreso de 1912, probablemente las más libres en la historia de México, fue baja incluso en el Distrito Federal. Los dos candidatos que recibieron la mayor parte de los votos para el Senado del Distrito Federal, Francisco León de la Barra, del Partido Católico, y Fernando Iglesias Calderón, del Partido Liberal Maderista Progresista, obtuvieron un total de 4431 y 5061 votos, respectivamente, en todo el Distrito; la suma de sus votos apenas excedió el número total de trabajadores de sexo masculino de las fábricas textiles del Distrito Federal. Marcos López Jiménez del PCP, ganó el segundo distrito, de mayoría trabajadora, con sólo 696 votos. ${ }^{55} \mathrm{El}$ Mexican Herald estimó que "el voto fue escaso, de no más del $20 \%$ de los votantes que en muchos lugares se tomaron el trabajo de asistir a las urnas". ${ }^{56} \mathrm{El}$ cónsul estadunidense en la ciudad de México observó después de las elecciones al Congreso, que "si bien reparé en muchos hombres bien vestidos, aparentemente profesionistas, junto a hombres de las clases trabajadoras, no vi a nadie de las clases más bajas o 'pelados' votando". 57 En gran parte, no se logró que las

"Gs Guerra, "Elecciones", 1990, pp. 264, 274; los resultados de la votación para el Distrito Federal usados aquí están tomados del Mexican Herald, 7 de julio de 1912.

${ }^{56}$ Mexican Herald, 2 de julio de 1912, p. 1

57 Véase Arnold Chanklin, ciudad de México, al secretario de Estado, 1 de julio de 1912 , en Records of the Department of State Relating to the Internal Affairs of Mexico, 1910. $1929,812.00 / 4408$, rollo de microfilm 19 , citado en Knight, "Working", 1984, pp. 51-79. grandes masas presentes en los mítines previos maderistas acudieran a votar, quiza por la moderación del programa "progresista liberal" y de los candidatos al Congreso, así como por la falta de fuertes organizaciones políticas laborales. Aparentemente, los trabajadores estaban prestos a tomar las calles pero no a emitir su voto. Madero y el PCP fueron incapaces de crear una estructura partidaria incluyente que estimulara a los trabajadores urbanos a votar por un programa político significativo. Los trabajadores, por su cuenta, y sin fuertes estructuras sindicales, no pudieron formar tampoco organizaciones políticas viables. Las elecciones al Congreso no lograron incorporar ni llamar la atención de "the great unwasbed" reunidos para apoyar a Madero en las manifestaciones públicas de los dos años anteriores.

Después de las elecciones, muchos miembros de las organizaciones laborales se desilusionaron de sus posibilidades de participación política directa y del apoyo que podían esperar de los representantes electos pertenecientes a otras clases. En el mismo mes de esos comicios, junio de 1912, ocurricron toda una serie de divisiones políticas como consecuencia de esta decepción. Muchos de los miembros radicales del Partido Liberal lo abandonaron respondiendo al reproche de Ricardo Flores Magón quien, desde Estados Unidos, declaró que unas elecciones no resolverían los problemas sociales de México. ${ }^{58}$

\footnotetext{
${ }^{58}$ Cockroft, Intellectual, 1968, p. 222.
} 
Una escisión similar se dio en el pequeño Partido Socialista Obrero, cuyo fundador, Zierold, y su grupo nuclear continuaron abogando por un papel electoral social de estilo democrático para las organizaciones laborales. Otros trabajadores calificados, como el sastre Luis Méndez y el mecánico Jacinto Huitrón, llegaron a rechazar desde dentro del partido, las elecciones y a acercarse más a los trabajadores organizados en su propio lugar de trabajo. Su grupo abandonó el partido en junio de $1912 \mathrm{y}$, al cabo de una semana, había formado otro anarquista llamado Luz. Meses más tarde, éste, junto con diversos grupos de artesanos y algunos intelectuales radicales que habían abandonado el Partido Liberal, como Díaz Soto y Ga$\mathrm{ma}$, se reunieron para fundar la Casa del Obrero Mundial.

Por último, ocurrió una división similar en el Partido Popular de los Trabajadores, cuyos vínculos crecientes con el recién creado Departamento del Trabajo y con el ministro de Gobernación, Jesús Flores Magón, lo hicieron depender cada vez más de los favores del gobierno. Aun así, el Partido Popular de los Trabajadores declaró que las elecciones eran una farsa y exigió su anulación. ${ }^{59}$ Los trabajadores que abandonaron cada una de estas organizaciones concluyeron que no sólo se encontraban en los márgenes de la política, sino también en los de la mayor parte de las luchas populares que, crecientemente, tenían lugar en las calles y en los lugares de trabajo. Su participación políti-

${ }^{59}$ Mexican Herald, 7 de julio de 1912. ca no provendría de un "sufragio efectivo" ni mucho menos de una defensa de los líderes electos, sino de organizarse en sus lugares de trabajo; $y$, para muchos, aunque no para la totalidad, el desarrollo de sus organizaciones sólo podría realizarse en contra de las autoridades políticas. El cambio gradual hacia la organización en el lugar del trabajo después de mediados de 1912, junto con el rompimiento inminente del orden democrático que conllevó la rebelión militar, puso fin a un ciclo de participación en la política electoral que había arrancado con la promesa de otorgar la libertad electoral en $1909 .^{60}$

\section{TRABAJADORES Y DIPUTADOS}

¿Cuáles fueron las relaciones de los trabajadores y de sus organizaciones con los miembros del Congreso? Esta pregunta requiere primero de un breve análisis de las organizaciones laborales de la ciudad de México y, en particular, de una institución clave surgida durante ese periodo: La Casa del Obrero [más tarde "Mundial"]. Fue producto de dos cambios en dichas organizaciones: uno de ellos fue la escisión consistente en un alejamiento de las sociedades de ayuda mutua, forma principal de organización laboral durante el porfiriato, para crear agrupaciones más militantes, las cuales se multiplicaron brevemente después de la caída de Díaz. El segundo fue un distanciamiento de

${ }^{60}$ Araiza, Historia, 1975, t. IIl, p. 14; Carr, "Marxism", 1983, p. 283. 
las aspiraciones y de la participación política que habían caracterizado a los trabajadores en los inicios de la revolución, para adoptar una posición pública de neutralidad política. Esta Casa se fundó en septiembre de 1912, apenas dos meses después de las elecciones al Congreso, fue como una combinación de un centro cultural y una federación informal de sindicatos. Congregó a diversas organizaciones, la mayoría de las cuales se referían a sí mismas como "sociedades de resistencia" y, al menos inicialmente, estuvieron dominadas por trabajadores calificados y, por empleados con un nivel de vida relativamente bueno. Ideológicamente, el liderazgo de la Casa defendía un anarquismo de inspiración española que llamaba a la acción directa y que rechazaba todas las alianzas políticas. Muchos de sus líderes habían tomado parte activa en organizaciones políticas: el impresor Rafael Quintero había movilizado a los trabajadores en favor de Madero en 1910, y el mecánico Jacinto Huitrón y el sastre Luis Méndez habían sido miembros del Partido Socialista Obrero. Más que un simple capricho, su rechazo de la política electoral y de las alianzas políticas a fines de $\mathbf{1 9 1 2}$ fue, en parte, el resultado de los fracasos previos de la democracia maderista para satisfacer las necesidades de los trabajadores. ${ }^{61}$

\footnotetext{
${ }^{61}$ Quintero editó el periódico promaderista de corta vida Evolución, 1 de mayo de 1910. Para las experiencias de Huitrón con el Partido Socialista de los Trabajadores y el rechazo de la Casa a la política electoral y las alianzas políticas, véase Huitrón, Origenes, 1984, p. 215.
}

Además de rechazar las estrategias electorales, los sindicatos afiliados a la Casa del Obrero rechazaron consistentemente, durante su primera época, cualquier intento del gobierno maderista, particularmente de su recién creado Departamento del Trabajo, de intervenir en los conflictos en los lugares de trabajo, incluso cuando lo hacía en favor de los obreros. A los trabajadores calificados de la Casa les fue relativamente fácil sostener esta posición, porque ocupaban un lugar más bien privilegiado dentro del mercado laboral; pero les fue más difícil a medida que la Casa empezó a organizarlos en ocupaciones menos calificadas $\mathrm{y}$ a incluir a las mujeres.

Además de los grupos laborales que componían el grueso de la Casa, algunas personas que simpatizaban con ella, a menudo de orígenes clasemedieros, se hicieron también miembros de la misma. Estos "intelectuales" jugaron un importante papel, tanto en su desarrollo como centro cultural, como en la définición de la cultura política de la organización. Intelectuales radicales de la estatura de Antonio Díaz Soto y Gama y Juan Sarabia participaron plenamente en sus actividades durante este periodo, si bien nunca llegaron a ocupar posiciones de liderazgo. Muchos de estos intelectuales habían pasado brevemente por las filas del PLM o por el grupo de los hermanos Flores Magón, así como por el más moderado Partido Liberal, antes de desilusionarse de la política. Por ejemplo, desde las páginas del periódico de la $\mathrm{Ca}$ sa del Obrero, El Sindicalista, Díaz Soto y Gama declaró, después del 


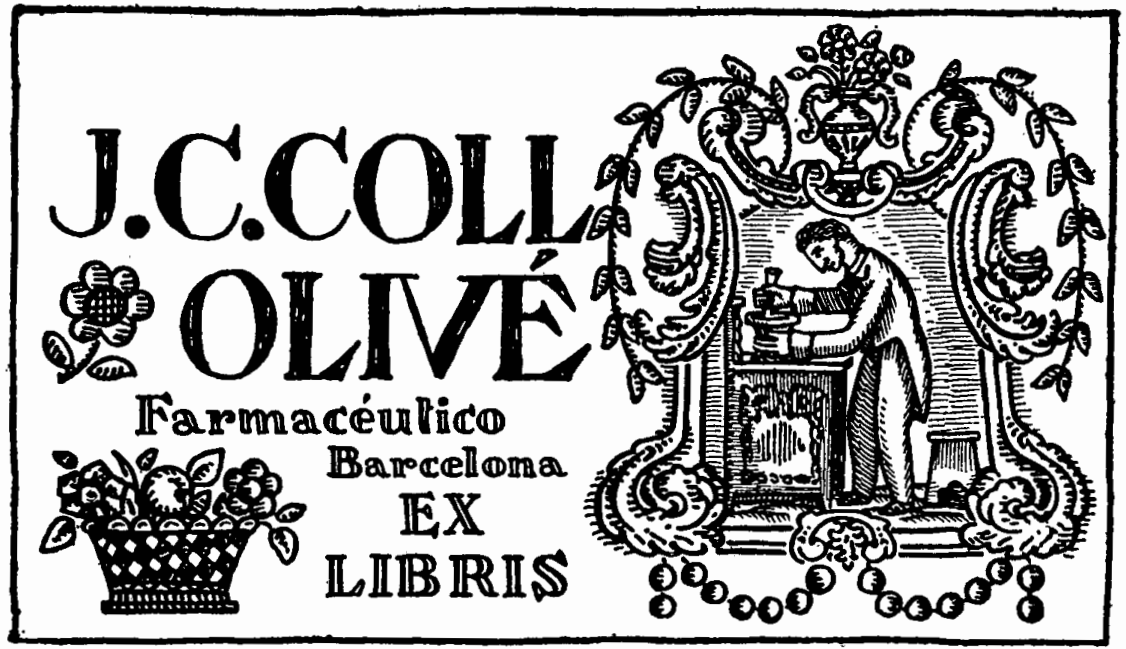

golpe de Huerta, que "pese a sus promesas, los políticos nunca salvarían a la clase trabajadora", puesto que esta salvación sólo vendría de los sindicatos y de la acción directa, de la huelga $y$ el boicot. ${ }^{62}$

Al mismo tiempo que la Casa del Obrero mantenía públicamente una posición de neutralidad política y que continuaba con sus estrategias de organización, primordialmente en el lugar de trabajo, muchos de estos intelectuales de clase media que fueron bienvenidos a sus filas, fungieron como diputados en el Congreso. Un antiguo miembro de la Casa, Luis Arai-

${ }^{62}$ El Sindicalista, 30 de septiembre de 1913, reimpreso en Huitrón, Orígenes, 1984, p. 241. $z a$, enlista siete diputados entre los primeros afiliados a ella, incluyendo a personajes claves del Bloque Renovador, como Serapio Rendón y Heriberto Jara ${ }^{63}$ La prominencia política de estos hombres en la XXV1 Legislatura, así como sus contribuciones financieras a la Casa, tanto como intelectuales como de diputados, dificultaron, aunque no imposibilitaron, la posición de neutralidad política de ésta ${ }^{64}$ Por lo menos un antiguo miem-

${ }^{63}$ Otros diputados de la Casa fueron Jesús Urueta, Hilario Carrillo, Jesús González y Román Morales. Araiza, Historia, 1975, t. III, p. 20.

${ }^{64}$ Para los problemas financieros y el apoyo monetario de estos intelectuales, véase Araiza, Historia, 1975, t. 111 , p. 48; sobre las relaciones con el PLM, véase Hart, Anarcbism, 1987, p. 129. 
bro de la misma, Francisco Ramírez Plancarte, dedujo que la Casa fue creada por diputados maderistas como una forma de llenar las galerías del Congreso y de contrarrestar a las multitudes reaccionarias movilizadas por el Partido Católico. Plancarte narró cómo en noviembre de 1912, durante el debate de una ley para establecer un impuesto relativo a las condiciones laborales en la industria textil, la Casa inundó la Cámara de Diputados con trabajadores blandiendo barras metálicas y amenazando a los par. tidarios católicos. La confrontación y el debate fueron seguidos por una marcha triunfante de los trabajadores y diputados camino a sus cuarteles. "Nuestra Casa es también la vuestra", declaró supuestamente el sastre y líder de ésta, Luis Méndez, al diputado Rendón. ${ }^{65}$ Pero si bien la Casa pudo haber movilizado a algunos grupos para apoyar esa ley (aun cuando en ese momento, los trabajadores tex. tiles eran una pequeña porción de su membresía), Ramírez Plancarte, al escribir en la década de 1940 , bien puede haber estado abiertamente influenciado por la versión "oficial" de la revolución, la cual tendió a institucionalizar y ampliar la alianza entre los trabajadores y las fuerzas revolucionarias. De todos modos, en otros momentos, la Casa del Obrero se opuso a las medidas e instituciones que salieron de la Convención Textil apoyada por Madero. ${ }^{66}$

\footnotetext{
${ }^{65}$ Ramírez Plancarte, Revolución, 1952, pp. $468,517$. 127.
}

Si bien los diputados locales participaron libremente en ella, ni la diseñaron ni dirigieron sus actividades. La estrategia fundamental de la Casa, que llegó a dominar crecientemente el movimiento laboral en la ciudad de México, entre 1912 y 1914, fue primordialmente la de organizar a los trabajadores en su lugar de trabajo y en su comunidad, y no por medio de las elecciones ni en la arena política.

Al mismo tiempo, a medida que expandía rápidamente su membresía e incorporaba a los trabajadores menos calificados y a las mujeres a sus filas, se enfrentó a una tensión entre la devoción a los principios, que muy probablemente la mantendrían distanciada de las luchas de la mayoría, y la búsqueda de alianzas políticas que, si bien le proporcionaban cierto apoyo frente a los patrones y prestigio ante la masa laboral, significaba por definición apartarse de los principios anarquistas y perder parcialmente la autonomía de sus organizaciones.

Además, a medida que la revolución avanzaba, se volvió crecientemente difícil para las organizaciones laborales mantener una posición de neutralidad política hacia el gobierno nacional, hacia los miembros del Congreso y hacia las facciones revolucionarias que luchaban por el poder. Con el tiempo, muchos trabajadores retiraron su apoyo a Francisco I. Madero debido a la falta de reformas laborales significativas. La administración maderista -especialmente el Departamento del Trabajo- permaneció hostil hacia las actividades de la Casa; no obstante, pese a los arrestos ocasionales de sus líderes y a la depor- 
tación de, al menos, un miembro colombiano anarquista, el gobierno le permitió existir. Como resultado, su posición hacia el gobierno maderista estuvo más cercana a la indiferencia que a una hostilidad abierta.

Después de la destitución de Madero en febrero de 1913, organizada por Victoriano Huerta, la situación cambió. Huerta consideró las huelgas y las movilizaciones laborales y populares como retos a su régimen, de modo que creció la hostilidad de su gobierno hacia la Casa. En este contexto, sus actividades adoptaron de manera creciente un aspecto de oposición, en paralelo con las dramáticas acciones del Bloque Renovador en el Congreso, que era la única fuerza de oposición interna a la dictadura de Huerta. Esta conflictiva relación quedó ejemplificada en la decisión de la Casa del Obrero, de organizar la celebración del primero de Mayo en 1913. Si bien al menos un historiador ha propuesto la celebración del primero de mayo como prueba de las tendencias laboristas reformistas de Huerta, de hecho fue ella la que la organizó, pese a la prohibición del gobierno huertista de que ésta se llevara a cabo al aire libre. ${ }^{67}$ Con la participación de 20000 trabajadores, el suceso se convirtió en el primer reto masivo y público a Huerta en la ciudad de México, desde el brutal derrocamiento y asesinato de Madero, dos meses antes. ${ }^{68}$ Como sus contrapartes en Europa, los organizadores vincularon el primero de mayo con la de-

\footnotetext{
${ }^{67}$ Meyer, Huerta, 1972 , p. 174.

${ }^{60}$ Lear, "Workers", 1993, pp. 284-289.
}

manda de una jornada de ocho horas, que sólo podía plantearse ante las autoridades políticas (en este caso, la única electa legítimamente era el Congreso). Después de algunos discursos en la Alameda, donde se exigían los derechos laborales y se denunciaba al régimen huertista, los trabajadores marcharon hasta la Cámara de Diputados en el corazón de la ciudad y presentaron un proyecto para legalizar la jornada laboral de ocho horas, y para obligar a los patrones a reconocer a los sindicatos y a indemnizar a los trabajadores por accidentes. La petición fue recibida cálidamente por un puñado de diputados del Bloque Renovador de oposición, como Heriberto Jara, quien jugó un papel en la organización de las celebraciones de ese primero de mayo. ${ }^{69}$ No obstante, el Congreso no discutió la totalidad de las propuestas presentadas ese día. Y si bien algunos miembros de los sindicatos se quejaron de que la marcha y la petición al Congreso comprometía la declarada neutralidad de la Casa del Obrero Mundial, su reto a Huerta y sus demandas políticas de reformas garantizaron la amplia participación de los trabajadores de la ciudad de México y del movimiento laboral en proceso. ${ }^{70}$

Para octubre de 1913, Huerta había disuelto el Congreso, luego de repetidos cuestionamientos de parte de los diputados renovadores; la mayoría

\footnotetext{
${ }^{69}$ Araiza, Historia, 1975, t. III, p. 39; Salazar y Escobedo, Pugnas, 1992, p. 63

${ }^{70}$ Salazar y Escobedo, Pugnas, 1992, p. 63. Sobre la decisión del sindicato de los impresores, véase Córdoba, "Movimiento", 1971, p. 83.
} 
de éstos escaparon en ese momento para unirse a las fuerzas constitucionalistas bajo las órdenes de Carranza. Pocos meses después, en mayo de 1914, Huerta cerró la Casa, en un acto de desesperación, durante las semanas previas a su derrota militar.

Cuando la Casa del Obrero reabrió sus puertas en el otoño de 1914, se enfrentó a una política muy distinta, en la cual, tanto las cortesías legales electoreras como la legislación en el Congreso carecían de significado, no obstante que la fuerza militar y el poder de decretar estaban en manos de hombres que se habían mostrado favorables a la causa de los trabajadores, como el ex diputado y miembro de la Casa, Heriberto Jara, a quien Carranza había designado gobernador del Distrito Federal. Esta situación, junto con la inminente escisión entre las fuerzas de la Convención y las constitucionalistas, constituyó un verdadero reto para la declarada neutralidad política de la Casa del Obrero, lo cual llevaría finalmente, al menos a una parte significativa del movimiento laboral de la ciudad de México (a aquéllos que firmaron el famoso pacto con los constitucionalistas para formar los Batallones Rojos), a convertirse, por el momento, en elementos "disponibles" para los caudillos militares norteños y futuros vencedores de la revolución. ${ }^{71}$

\footnotetext{
${ }^{71}$ Me ocupo de las circunstancias que rodearon al pacto en "Workers", 1993, cap. 7. Vale la pena mencionar aquí que por lo menos una porción significativa de la membresía de la Casa rechazó el pacto y permaneció bajo una organización activa en la ciudad de México durante la ausencia de los Batallones Rojos.
}

EL CONGRESO Y IA REFORMA IABORAI.

¿En qué medida la XXVI Legislatura se abocó a resolver las necesidades de los trabajadores? En última instancia, el papel del Congreso y su interacción con los trabajadores debe evaluarse por la legislación propuesta y las leyes aprobadas. El gobierno de Madero en su conjunto resultó incapaz de responder adecuadamente a estas necesidades. Acosado por las presiones de sus antiguos aliados revolucionarios (Orozco, Zapata y Vázquez Gómez), así como por parte de los elementos privilegiados del orden porfiriano (la Iglesia, los militares, los ricos terratenientes, los científicos), Madero y su gabinete actuaron con suma lentitud para proponer una legislación social significativa que favoreciera a los trabajadores. El Congreso, durante los escasos meses que sesionó bajo la administración maderista -congruente con el líder nacional-, no adoptó una política laboral definida ni tuvo iniciativas propias.

El Congreso mismo se encontraba dividido entre una fluctuante y escasa mayoría maderista y una minoría consistente y definida de diputados que eran verdaderamente independientes, quienes, sin embargo, se identificaban con el régimen porfirista, o bien estaban afiliados al nuevo Partido Católico. El propio grupo maderista en el Congreso estaba dividido entre una mayoría conservadora centrada en apoyar al presidente en su cauteloso camino de establecer negociaciones con los elementos porfiristas para una reforma acotada, y una facción, pequeña pero articulada, al 
menos durante las semanas previas al golpe huertista, que presionó para que se hicieran reformas más radicales que cumplieran las promesas formuladas por la revolución que había derrocado a Díaz. ${ }^{72}$ La combinación de las dudas de Madero con la diversidad de opiniones y de divisiones faccionales existentes dentro del Congreso -ambos factores, signos dramáticos de la escisión de la mayoría en la era porfiriana y tal vez muestra de un incipiente proceso democrático-, obstaculizó, en el corto plazo, cualquier elaboración efectiva de una verdadera reforma social, ya fuera en el área agraria o en las cuestiones laborales. Tanto Madero como la XXVI Legislatura sólo contarían con un plazo corto.

La política laboral de Madero consistió, primordialmente, en dos líneas en que participó el Congreso de manera muy limitada: la primera fue la creación del Departamento del Trabajo; la segunda, responder sólo a las huelgas e incluso, en este caso, sólo a aquellas que representaban amenazas directas al orden económico y social, como las textiles que se iniciaron días después de que el presidente asumiera el poder. Esta huelga estimularía a Madero a emprender su más significativa iniciativa laboral: la organización de la Convención Textil.

El Departamento del Trabajo fue creado durante la presidencia interina de De la Barra, y aprobado por la XXV Legislatura; pero en realidad,

\footnotetext{
72 Para los grupos existentes dentro del Congreso, véase Piccato, Congreso, 1991, pp. 90-92.
}

la iniciativa surgió bajo la dirección de Madero y es en ese sentido que representaba las metas de la administración maderista. Estas metas consistían en asegurar la paz industrial evitando y resolviendo los conflictos entre los trabajadores y los patrones; protegiendo a las mujeres y los niños en sus centros de trabajo y desalentando a las organizaciones militantes e independientes de los trabajadores. El arbitraje de parte del Departamento requería del consentimiento tanto de Ios trabajadores como de los patrones, pero incluso en ese caso el acuerdo al que se llegara no era obligatorio. En contraste con las funciones voluntarias de arbitraje de parte del Departamento, había sido estipulado que las organizaciones laborales de. berían registrarse en la dependencia, aun cuando carecieran de un estatus legal dentro de las leyes mexicanas. ${ }^{73}$ El Departamento del Trabajo intentó formalizar en gran medida el patronazgo y los papeles mediadores de los funcionarios públicos bajo Porfirio Díaz y jugó un papel importante en el desarrollo de la política laboral del gobierno posrevolucionario; pero tenía una autoridad legal y moral limitada para imponer una solución a los conflictos laborales, de modo que, tanto el liderazgo de la Casa como los trabajadores más calificados y los sindicatos más independientes de la ciudad, lo veían con desconfianza. Además, estaba encargado de hacer un código laboral federal, si bien para la época del golpe huertista había avan$59: 4$

${ }^{73}$ AGN, Departamento del Trabajo, 55:8 y 
zado poco en este sentido, fuera de elaborar algunos documentos internos que proponían reformas muy modestas, la mayor parte de las cuales se relacionaban con las condiciones laborales de las mujeres y los niños. ${ }^{74}$

Otra iniciativa importante del gobierno maderista fue la ley fiscal en el ramo textil, que llegó a ser conocida como la Ley Obrera. Sus orígenes se ubican en las huelgas masivas y nacionales de los trabajadores textiles que tuvieron lugar en la última semana de 1911, poco después de que Madero asumiera el poder. El presidente respondió a las huelgas reuniendo una Junta de Industriales en enero de 1912, seguida en julio de una Convención Textil, a la que asistieron representantes tanto de los trabajadores como de los industriales. Los obreros textiles desempeñaron un papel secundario en las negociaciones mismas, pues nunca se les permitió reunirse con los industriales, ni éstos consideraron su propia propuesta; no obstante, obtuvieron algunos beneficios significativos de los acuerdos, como la confirmación de una jornada labo. ral de diez horas, limitaciones al muy repudiado sistema de multas, así como un complejo sistema de salarios mínimos que intentaba uniformar los salarios más bajos en todo el país. La limitante burocrática más grande de

\footnotetext{
${ }^{74}$ En AGN, Departamento del Trabajo, se encuentran resúmenes de los proyectos de leyes laborales, 56:1, proyecto de ley, art. 72, donde se propone una ley al Congreso para regular las condiciones laborales en diversas industrias, siguiendo el modelo de la convención textil.
}

estos acuerdos, fue que además de no reconocerse el derecho de los trabajadores a organizarse, la observancia de sus términos de parte de los industriales resultó enteramente voluntaria. ${ }^{75}$ En suma, la Convención Textil y las regulaciones laborales consecuentes fueron un precedente, preliminar pero importante, para modelos posteriores con respecto a la intervención estatal en las relaciones entre patrones y trabajadores. Pero si bien constituyó un paso que dejó atrás, de manera significativa, las intervenciones del Estado porfiriano en materia laboral, sus metas y métodos fueron modestos, si se los juzga por los estándares europeos, y muy lejanos de los que incorporaría más tarde la Constitución de 1917.

La Convención Textil fue orquestada desde arriba por Gustavo Madero, hermano del presidente, y por Rafael Hernández, secretario de Fomento, mientras que la parte instrumental de la organización recayó en el Departamento del Trabajo. El Congreso, en la época de las huelgas textiles y de la convención, seguía dominado por diputados electos bajo Porfirio Díaz, y no jugó ningún papel en este proceso, aun cuando algunas propuestas laborales menores sí fueron discutidas pero no aprobadas por Ia XXV Legislatura. ${ }^{76}$

${ }^{75}$ Sobre la participación de los trabajadores en las huelgas y la convención, véase Lear, "Workers", 1993, pp. 253-263. Sobre los términos de la convención, véase Ramírez Rancaño, Burguesia, 1987, pp. 76-80.

${ }^{76}$ Palavicini, Diputados, 1976, pp. 567-569. 
La recién instalada XXVI Legislatura se hizo cargo del problema meses después, y a iniciativa de los industriales, más que de los trabajadores. Como se mencionó, el problema clave de los acuerdos de la Convención Textil residió en su observancia discrecional. A pocas semanas de la aprobación de la convención, y después de una segunda ola de huelgas entre los trabajadores textiles, furiosos por la indiferencia de los patronos para poner en práctica los acuerdos, se reunió un Comité de Industriales que decidió solicitar al presidente Madero una reducción de impuestos a la producción textil de 5 a $4 \%$, como premio por aplicar las tasas salariales especificadas en la convención. Madero estudió la propuesta y elevó el impuesto de 5 a $8 \%$, pero ofreció una rebaja de $4 \%$ a quienes observaran voluntariamente los acuerdos. Un cambio fiscal tal requería de la aprobación del Congreso, pues se trataba en esencia de un subsidio solicitado por los industriales, a cambio de la aplicación de tales acuerdos. ${ }^{77}$ Así, lo que llegó a conocerse como la Ley Obrera, fue en realidad una ley fiscal, si bien, también era, a nivel simbólico, una manera de endosar las regulaciones al salario nacional y las condiciones laborales, tal y como las había negociado el ejecutivo durante la Convención Textil.

En cualquier caso, la ley fiscal otorgó a los diputados una oportunidad dilatada de debatir la llamada "cuestión obrera", que se trató de manera $87-90$

${ }^{77}$ Ramírez Rancaño, Burguesía, 1987, pp. intermitente desde la primera lectura de la ley, el 25 de septiembre, hasta que se aprobó, el 12 de diciembre. ${ }^{78}$ Pese a sus beneficios limitados e indirectos, hubo un apoyo significativo a la ley de parte de los trabajadores, quienes consideraron que se habían obtenido ganancias netas con los acuerdos de la convención, y que la rebaja fiscal aseguraría su observancia de parte de los industriales. Los trabajadores de 114 fábricas textiles enviaron una petición a los diputados, solicitando la aprobación de la ley. Además es claro, según los registros del debate lleno de observaciones dirigidas al público y de gritos frecuentes, que las galerías de la Cámara de Diputados estaban repletas de trabajadores. Al mismo tiempo, no se hace mención alguna ni en el curso de los debates ni en los recuentos de los periódicos, de la presencia de miembros de la Casa del Obrero Mundial, que apenas había sido fundada semanas antes de la discusión de la ley. ${ }^{79}$

Dados los objetivos modestos, c incluso conservadores, de la ley fiscal, y la presencia de los trabajadores en las galerías, pocos diputados estuvicron dispuestos a oponerse a la ley, incluso si no estaban de acuerdo con algunos aspectos de los acuerdos de la convención. La tendencia general del debate fue de apoyo a la medida fiscal y a la convención, así como a la formulación de promesas vagas de legislaciones futuras en beneficio de

${ }^{78} \mathrm{El}$ recuento más accesible del debate de la Ley Obrera se encuentra en Arenas, Historia, vol III.

${ }^{79}$ Ibid., p. 17. 
los obreros. De hecho, en el dictamen presentado de manera conjunta por miembros de las comisiones de Fomento, Hacienda y Puntos Constitucionales, se reconocía que la medida era "altamente política, ya que por primera vez se toma una medida legislativa que se encamine directamente a beneficiar a la clase trabajadora". ${ }^{80}$

Aun cuando todos los participantes en el debate declararon estar interesados en el mejoramiento de las condiciones laborales, los diputados atacaron o apoyaron algunos aspectos de los acuerdos de la convención, no obstante que al Congreso sólo se le había solicitado que resolviera en torno a una ley fiscal que beneficiaría a los industriales que observaran los acuerdos. Más aún, los diputados delinearon, en el curso del debate, sus posiciones con respecto a leyes futuras que regularan las relaciones laborales entre trabajadores y patrones, así como las perspectivas de los trabajadores a los que esperaban beneficiar.

La limitada oposición a la ley fiscal y a la Convención Textil fue liderada por Carlos Zetina, el candidato del Partido Liberal, dueño de una fábrica de zapatos, quien había solicitado el apoyo de los obreros de Tacubaya durante las elecciones de junio. Zetina argumentaba que, al presionar a los industriales a fijar salarios, el gobierno violaba las leyes del libre mercado. Una consecuencia de ello, afirmaba, era que los niveles salariales más altos ocasionarían problemas económicos a los industriales, particularmente a las pequeñas empresas que no podrían

${ }^{80}$ Ibid., p. 20. pagarlos; este punto fue secundado y ampliado en la intervención del cliputado de Puebla, José Mariano Pontón. Los consumidores pobres, afirmaban ambos diputados, serían quienes pagarían precios más altos por los textiles básicos producidos en la mayor parte de las fábricas, lo cual afectaría a los mismos grupos que los diputados esperaban beneficiar. Lo peor de todo, según Zetina, era que la Convención Textil sería apenas el principio de una cadena: inevitablemente, los trabajadores de otros sectores seguirían el mismo camino y exigirían demandas similares.

A un nivel distinto, Zetina argumentaba desde su propia experiencia ("tengo como hijos a setecientos obreros"), que los trabajadores no estaban moralmente preparados para un alza salarial: "¿Qué hace un hombre que está ganando cuatro reales y mañana tiene doce? ¿En qué emplea esos doce reales si no tiene necesidades?" Su respuesta, que los trabajadores en la sala parecieron anticipar con sus gritos furiosos fue: "No trabajar, irse a la pulquería a gastarlos".81

La mayoría, dirigida por los diputados del Bloque Renovador, expresó su apoyo a la ley y demandó que se hiciera "todo lo posible para ayudar al trabajador". La defensa de la ley corrió a cargo del diputado Heriberto Jara, que había participado en la comisión conjunta que presentó la ley y que desempeñaría un papel similar, pocos años más tarde, en la elaboración del artículo 123, durante la Convención Constitucional de Querétaro.

${ }^{81}$ Ibid., pp. 25, 45-50, 88, 90. 


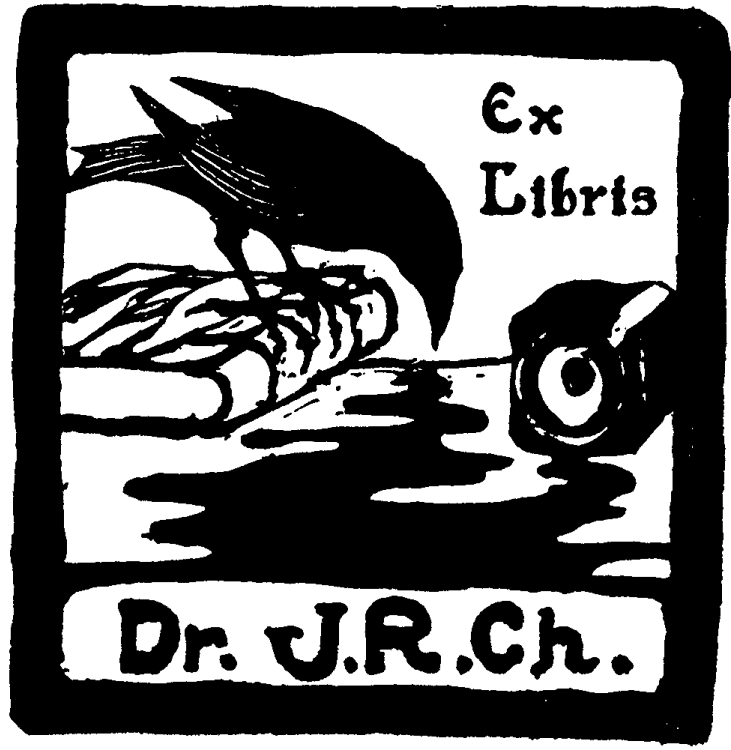

Jara se levantó repetidas veces para responder a cada crítica de la ley, insistiendo en que la regulación salarial era del arbitrio del gobierno, y excitaba a los trabajadores de otros sectores a que demandaran los mismos derechos. Jara invocó al fantasma de los sucesos de Río Blanco y Cananea, advirtiendo que, de otro modo, "esos míseros, recordando que son hombres, se yergan, se levanten y clamen por los suyos, y nos estrechen, nos ahoguen a los que no hemos podido hacer nada por ellos". ${ }^{82}$

La ley recibió un fuerte apoyo de dos de las facciones más terriblemente opuestas entre sí dentro del Congreso: los renovadores y los cató-

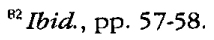

licos. Ciertamente, gran parte del debate se centró en cuál de los partidos -católico, progresista y liberal- se inclinaba más a ayudar a los trabajadores. El importante diputado del Partido Católico, Francisco Elguero, denunció diversas tendencias socialistas en Europa y en México e invocó la encíclica Rerum Novarum del Papa León XIII, con su llamado a proporcionar un salario familiar. ${ }^{83}$ Algunos diputados, como los del Partido Católico, pretendieron ser los primeros en haberse abocado a la cuestión social en México, y ciertamente podían señalar (como hacen los historiadores de la Iglesia católica en México) importantes leyes laborales pasadas por

${ }^{83}$ Palavicini, Diputados, 1976, pp. 200-202. 
la Legislatura del estado de Jalisco, controlado por el Partido Católico. ${ }^{84}$ Otros renovadores, como Juan Sarabia y Serapio Rendón, empleaban más tiempo en atacar al diputado Elguero, que apoyaba la ley con base en la defensa de la caridad católica como una llave para la salvación del trabajador, que en rebatir a los diputados Pontón o Zetina, opuestos a la ley. El diputado Jesús Macías, defensor de la misma, hizo referencias constantes a los pensadores socialistas europeos y se refirió a la teoría del valor para justificar la tendencia mexicana hacia el socialismo en el campo del trabajo. Aun así, Macías compartía con Zetina un cierto desprecio por los trabajadores mexicanos; la presente medida era un pequeño paso hacia el socialismo, explicó, que tendría que aguardar hasta que "el operario se haya ilustrado, cuando el operario tenga una inteligencia más llena de verdad, cuando se haya retirado de los vicios... en una palabra, cuando tengamos el operario belga". ${ }^{85}$

Finalmente, la ley se aprobó por un amplio margen, y fue firmada por Madero el 12 de diciembre de 1912. Lo que destaca de este debate que se extendió por dos meses, es que difícilmente se planteó o elaboró una propuesta concreta en el campo de la legislación laboral, aun cuando varios diputados mencionaron proyectos

\footnotetext{
${ }^{84}$ Las reformas del Partido Católico en Jalisco desalentaron en gran medida las huelgas, pero otorgaron un estatus legal a las organizaciones laborales y estimularon la creación de cooperativas, Quirk, Mexican, 1973, p. 32.

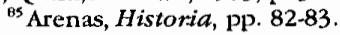

que se referían a demandas comunes entre los trabajadores de todos los sectores. La más aproximada, fue una enmienda a la ley fiscal textil, introducida durante el debate por los diputados Jara, Jesús Urueta y José Lozano, elaborada desde el punto de vista de la comisión que presentó la ley. Esta enmienda hubiera permitido al gobierno devolver el $4 \%$ del impuesto directamente a los trabajadores, en lugar de a los propietarios, en aquellas fábricas donde no se observaran los términos de la Convención Textil; pero se aprobó la ley original, dejando la enmienda dentro de las discusiones de la comisión, de donde nunca más saldría. ${ }^{86}$

Además del fracaso de la enmienda, surgieron otras propuestas sólo como especulaciones a futuro. Desde luego, al presentar la ley fiscal, la comisión había prometido que en lo sucesivo, el gobierno daría a la clase trabajadora

otras varias disposiciones que tiendan a protegerla de una manera eficaz y directa, ya asegurándola contra accidentes, ya reglamentando el trabajo, procurándoles comodidad y salubridad en él; ya garantizándoles la plena libertad para la formación y funcionamiento de las asociaciones y sindicatos de obreros; ya favoreciendo y protegienclo a las asociaciones de enseñanza y recreo. La formación de sociedades cooperativas y de consumo $y$, en una palabra, de todo cuanto eleve el nivel moral, físico y cconómico del obrero. ${ }^{87}$

\footnotetext{
${ }^{86}$ Ibid., pp. 95, 181-189.

${ }^{87}$ Ibid., pp. 20.
} 
Estos proyectos futuros hallaron eco, con variaciones mínimas, en las propuestas de varios diputados dentro del contexto del debate. El diputado católico Elguero propuso el apoyo del gobierno para crear cooperativas y cajas de ahorro; el industrial Zetina recomendó el establecimiento de escuelas industriales que podrían facilitar la preparación de gerentes de nivel medio; varios diputados mencionaron la necesidad de dictar una ley para que se indemnizara a los trabajadores que sufrieran accidentes en el trabajo. Pero sólo uno, Salvador Moreno Arriaga, planteó lo que era una de las demandas claves de las organizaciones laborales de todo el país: la necesidad de dar, a las sociedades de ayuda mutua y a los sindicatos, una "personalidad jurídica", un estatus legal formal que permitiera a estas organizaciones adquirir propiedades, aparecer ante las autoridades como "personas morales" y, lo que era más importante, negociar contratos colectivos de trabajo directamente con los patrones. ${ }^{88}$

Opuesto a la ley, el diputado Ponzón afirmaba, con razón, que lo que realmente se requería era una ley del trabajo. El diputado veracruzano Miguel Hernández Jáuregui preguntó por qué los Renovadores no habían presentado, simplemente, un proyecto de reforma al Ministerio del Trabajo, o por qué no habían elaborado una ley para regular la jornada laboral, legalizar las huelgas, proteger a las mujeres e indemnizar a los traba-

\footnotetext{
${ }^{8}$ Palavicini, Diputados, 1976 , pp. 199-205; Arenas, Historia, pp. 50-52.
}

jadores que sufrieran accidentes, en una palabra: "¿por qué no procedemos a la creación y a la formación del Derecho Obrero, señores, que es el aseguramiento de la felicidad actual y porvenir?" ${ }^{89}$

Pero ninguna de las propuestas individuales o globales planteadas durante el debate, llegaron a convertirse en una iniciativa formal en las escasas semanas que le restaban al gobierno maderista. Para cuando se dio el golpe huertista en febrero de 1913 , ni el gabinete de Madero ni el Congreso habían generado las reformas prometidas para proteger a los trabajadores, con la modesta excepción de la Convención Textil y la ley fiscal.

Bajo el gobierno de Huerta, el Departamento del Trabajo siguió elaborando propuestas laborales. A fines de mayo de 1913, tal vez en respuesta a las movilizaciones del primero de mayo y a las peticiones de la Casa del Obrero, presentó al Congreso una reforma constitucional que otorgara poder al mismo "para expedir leyes industriales y de minería, comercio e instituciones de crédito", y que fuera obligatoria en toda la república: pero la ley seguía pendiente meses después, cuando Huerta disolvió el Congreso en octubre de $1913 .^{90}$ En abril, los diputados conservadores y católicos presentaron una iniciativa que establecería el domingo como día de descanso y, en mayo, otra que otorgaría personalidad jurídica a las "Uniones Profesionales", pero estas leyes se

\footnotetext{
${ }^{89}$ Arenas, Historia, pp. 98-99.

${ }^{90}$ Propuesta del Departamento, fechada el 27 de mayo de 1913, en AGN, DT, 56:1.
} 
extinguieron de manera similar, en el seno de la comisión..$^{91}$

Hacia el fin del debate en torno a la ley fiscal, Luis Cabrera, el diputado progresista que presidía las discusiones, se quejó ante la Cámara de que se empleaba demasiado tiempo en las cuestiones laborales en lugar de exponer asuntos más importantes, como el de una reforma agraria; un punto válido, excepto por el hecho de que el prolongado debate sobre las cuestiones laborales, surgido en el contexto de la ley fiscal textil, sólo produjo eso: una medida a la que el diputado Querido Moheno se referiría como "la gorra que se tira al oso para retardar su zarpazo". ${ }^{92}$

En suma, la XXVI Legislatura, de corta vida, tuvo un historial poco memorable en cuanto a reformas laborales significativas. Si bien su fracaso en el impulso de éstas, difícilmente puede dar cuenta del colapso final del gobierno maderista, tal vez sugiere los problemas más amplios enfrentados por la administración maderista y la XXVI Legislatura. En la Decena Trágica de febrero de 1913, muchos trabajadores de la ciudad de México ya no estaban dispuestos a apoyar al régimen de Madero en su crisis final. Y cuando Huerta disolvió el Congreso, en octubre de 1913, hacía tiempo que habían abandonado las urnas electorales y las galerías del Congreso Federal y habían vuelto a sus luchas dentro de las fábricas, los talleres y en las calles.

\footnotetext{
${ }^{91}$ Palavicini, Diputados, 1976 , pp. 564-566.

${ }^{92}$ Arenas, Historia, pp. 105; Cumberland, Mexican, 1952, p. 228.
}

LOS TRABAJADORES Y IA PARTICIPACIÓN POLÍTICA MÁS ALLÁ DE LA

XXVI LEGISLATURA

Mi hipótesis tentativa sobre la participación política de los trabajadores comparte la ambigüedad inherente en la cita inicial de Alan Knight: por una parte, diferentes grupos de trabajadores se asociaron en distintas formas, de acuerdo con sus posiciones laborales y culturales en el contexto urbano; y por otra, según las oportunidades y lecciones que la revolución les ofreció. Aun así, tal vez sea posible trazar una tendencia general de las estrategias predominantes entre los trabajadores de la ciudad de México. Los dilemas que mencioné al principio, entre las estrategias económicas y las políticas, y entre las estrategias autónomas y las clientelares, pueden ser considerados como un ejercicio de dialéctica. Un científico con gusto por las gráficas podría bosquejar la tendencia de la clase obrera a través del tiempo: un eje se movería entre las estrategias políticas y las sociales, y otro entre la política autónoma y la clientelar. La línea para los primeros años de la revolución mexicana podría trazarse de la siguiente manera: en principio, los trabajadores urbanos de la ciudad de México aprovecharon las oportunidades de la expresión política relativamente libre, producida por las elecciones presidenciales, municipales y al Congreso entre 1910 y 1912 ; pero a medida que los procesos políticos resultaron ineficientes y desilusionantes, algunos sectores clave de la clase trabajadora rechazaron gradualmente la partici- 
pación política, y favorecieron un movimiento laboral más autónomo, enfocado hacia el lugar de trabajo y hacia su movilización dentro de la comunidad. Aun cuando este movimiento era a menudo negociado y de corta duración, sugiere una variedad de estrategias laborales en las décadas revolucionarias que, por lo menos, modifican las generalizaciones en torno a la "disposición de los trabajadores a establecer alianzas políticas y a participar en el poder". ${ }^{33}$

¿Cómo afectaron a los trabajadores de la ciudad de México sus experiencias con la XXVI Legislatura en el largo plazo, en el México posrevolucionario? Si se trazara la ruta de su participación política más allá de la XXVI Legislatura, uno podría encontrarse con la repetición de estrategias y patrones variados por los trabajadores, así como con un cambio definitivo hacia la participación política clientelar. La división entre convencionistas y constitucionalistas, en 1914 y 1915, constituyó una ruptura abrupta en el movimiento laboral de la ciudad de México, entre quienes se unieron a los Batallones Rojos y se convirtieron, de hecho (si bien brevemente), en clientes de Carranza y Obregón, y quienes permanecieron y preservaron el impulso de una organización laboral autónoma y de una relación respetuosa con la Conven. ción Revolucionaria. Después de la disolución de estos Batallones, y ante la ausencia continuada de un orden constitucional, los trabajadores de la ciudad de México iniciaron un ciclo

${ }^{93}$ Knight, "Working", 1984, p. 459. de organización autónoma que rechazó o reinterpretó sus alianzas políticas previas con los constitucionalistas y que culminó con la instrumentación de la herramienta central de la acción directa: la huelga general de julio de 1916.

Otro ciclo surge después de la supresión del movimiento laboral en 1916 y de la promulgación de la Constitución de 1917. Mis investigaciones en torno al periodo entre 1917 y 1920 apuntan a que los trabajadores comenzaron a aprovechar todas las oportunidades de participación en el proceso político y que intentaron formar parte del Congreso a través de partidos conformados por trabajadores diversos y relativamente autónomos, pero que, en gran medida, sus esfuerzos resultaron fallidos. Por ejemplo, en 1918, el recién formado Partido Socialista Obrero propuso a varios obreros, en su mayor parte veteranos en el liderazgo de la Casa del Obrero, como candidatos a la XXVII Legislatura. ${ }^{94}$ Esta estrategia fue un tipo inicial de acción múltiple que, debido en parte a la hostilidad mutua entre Carranza y los trabajadores de la ciudad de México, parece no haber recibido mucho apoyo de los líderes políticos y, por consiguiente, corrió con poco éxito en la arena electoral. Ante la ausencia de un fuerte movimiento sindicalista (la Casa ya había fenecido para entonces), los partidos autónomos de trabajadores se habían dividido de nuevo entre los que

${ }^{94}$ Los candidatos incluyeron a Jacinto Huitrón y Luis Morones. Salazar y Escobedo, Pugnas, 1992, pp. 235-236. 
rechazaban cualquier participación política (que se agruparon después de 1921 en la Confederación General de Trabajadores, CGT), y los que eligieron formar, en 1919, el Partido Laborista (asociado a la Confederación Regional de Obreros Mexicanos, CROM). La decisión del Partido Laborista de establecer una alianza con Álvaro Obregón -de ofrecerse como "disponibles"- cimentó la forma y el carácter de la participación política de los trabajadores durante la siguiente década, cuando el Partido Laborista llegó a convertirse en una facción clave dentro del Congreso federal. Finalmente, al término de la década de 1940, los trabajadores se encaminarían de manera drástica y aparentemente permanente hacia el lado político y clientelar de estos dos ejes.

\section{ARCHIVOS}

-AGN, Archivo General de la Nación, Departamento del Trabajo, 55:8; 59:4; 56:1. Gobernación 4a: 910-11 (8) (2); 2 (6). Periodo Revolución, 130: 48:2.

AHCM, Archivo Histórico de la Ciudad de México, 404:755-766, 3841-Regidores; Partidos políticos, 1300:23.

AHCD, Elecciones de Poderes Federales, 877 , exp. 80,81

\section{HEMEROGRAFÍA}

La Fuerza Obrera, 1912

Nueva Era, 1911, 1912

El Radical, 1911

El Obrero Mexicano, 1910, 1911

México Nuevo, 1909, 1910

Evolución, 1910
Mexican Herald, 1910, 1912

Juan Panadero, 1911

El Renovador, 1915

\section{BIBIIOGRAFÍA}

-Anderson Rodney D., Outcasts in their own land: mexican industrial workers, 1906-1911, Northern Illinois University Press, Dekalb, 1976.

-Mexican workers and the politics of revolution, 1906-1911", Hispanic American Historical Review, núm. 54, 1974.

-Araiza, Luis, Historia del movimiento obrero mexicano, México, 1964-1966, 1975 , t. III.

-Arenas Guzmán, Diego, Historia de la Cámara de Diputados de la XXVI Legislatura federal, s.p.i., vol. III.

-Ávila Espinosa, Felipe Arturo, "La sociedad mutualista y moralizadora de obreros del Distrito Federal (1909-1911)", Historia Mexicana, vol. 43, t. I, julio-septiembre de 1993.

-Camp, Roderic, Mexican, political biographies, University of Texas, Austin, 1991.

-Carr, "Marxism and anarchism in the formation of the Communist Party", Hispanic American Historical Review, vol. 63, núm. 2, 1983.

-Casasola, Gustavo, Historia gráfica de la revolución mexicana, México, 1960, vol. I.

-Cockroft, Intellectual precursors of the mexican revolution, 1900-1913, University of Texas Press, Austin, 1968.

-Córdoba Pérez, Fernando, "El movimiento anarquista en México (1911. 1921)", tesis de licenciatura, Facultad de Ciencias Políticas y Sociales- UNAM, México, 1971.

-Cumberland, Charles C., The mexican revolution: genesis under Madero, University of Texas Press, Austin, 1952. 
-González Navarro, Moisés, Historia moderna de México. El porfiriato. La vida social, El Colegio de México, México, 1957.

México Nuevo, 26 de abril de 1909.

-Guerra, François-Xavier, "Las elecciones legislativas de la revolución mexicana, 1912", Revista Mexicana de Sociología, vol. 52, t. 2, México, 1990.

-Hart, John M., Anarchism and the mexican working class, 1860-1931, University of Texas Press, Austin, 1978-1987.

-Huitrón, Jacinto, Orígenes e bistoria del movimiento obrero en México, Editores Mexicanos Unidos, México, 1984.

-Illades, Carlos, Hacia la república del trabajo: la organización artesanal en la ciudad de México, 1853-1876, El Colegio de México/UAM, México, 1996.

-Knight, Alan, "The working class and the mexican revolution c. 1900-1920", Journal of Latin American Studies, núm. 16, 1984, pp. 51-79.

, The mexican revolution, Cambridge University Press, Cambridge, 1986, vol. I.

-Leal, Juan Felipe y José Villaseñor, $L a$ clase obrera en la bistoria de México en la revolución, Siglo XXI, México, 1988.

-Lear, John, "Workers, vecinos and citizens: the revolution in Mexico city, 1909 1917", tesis doctoral, Universidad de California, Berkeley, 1993.

-Meyer, Michael C., Huerta: a political portrait, University of Nebraska, Lincoln, 1972.

-Morgan, Tony, "Proletarians, politics and patriarchs: the use and abuse of cultural customs in the early industrialization of Mexico city, 1880-1910" en William Beezley, Cheryl Martin y William French,
Rituals of rule, rituals of resistance, Scholarly Resources, Williamtown, 1994.

-Palavicini, Félix, Los diputados, México, 1976.

-Piccato, Pablo, Congreso y revolución, INEHRM, México, 1991.

-Quirk, Robert E., The mexican revolu. tion and the catbolic Church, 1910-1929, Indiana University Press, Bloomington, 1973.

-Ramírez Plancarte, Francisco, I.a revolución mexicana, México, 1952.

-Ramírez Rancaño, Mario, Burguesía textil y política en la revolución mexicana, s.e., México, 1987.

-Rodríguez Kuri, Ariel, La expertencia olvidada: el Ayuntamiento de México: política y gobierno 1876-1912, El Colegio de México/UAM, México, 1996.

-Salazar, Rosendo y José Escobedo, Las pugnas de la gleba, Ed. Avante, México, 1992.

-Vera Estañol, Jorge, Historia de la revolución mexicana, Porrúa, México, 1976. México, 1957. La revolución mexicana,

-Walker, David, "Porfirian labor politics: working class organizations in Mexico city and Porfirio Díaz, 1876-1912", The Americas, vol. 37, t. 3, 1981.

Warren, Richard A., "The will of the nation political participation in Mexico, 18081836", ponencia presentada en el XVII Congreso Internacional de las Asociación de Estudios Latinoamericanos, Los Ángeles, 1992.

-Womack, John Jr., "Luchas sindicales y liberalismo social" en Libertad y justicia en las sociedades modernas, Porrúa, México, 1994.

-Zapata Vela, Carlos, Conversaciones con Heriberto Jara, Costa Amic Editores, México, s.a. 

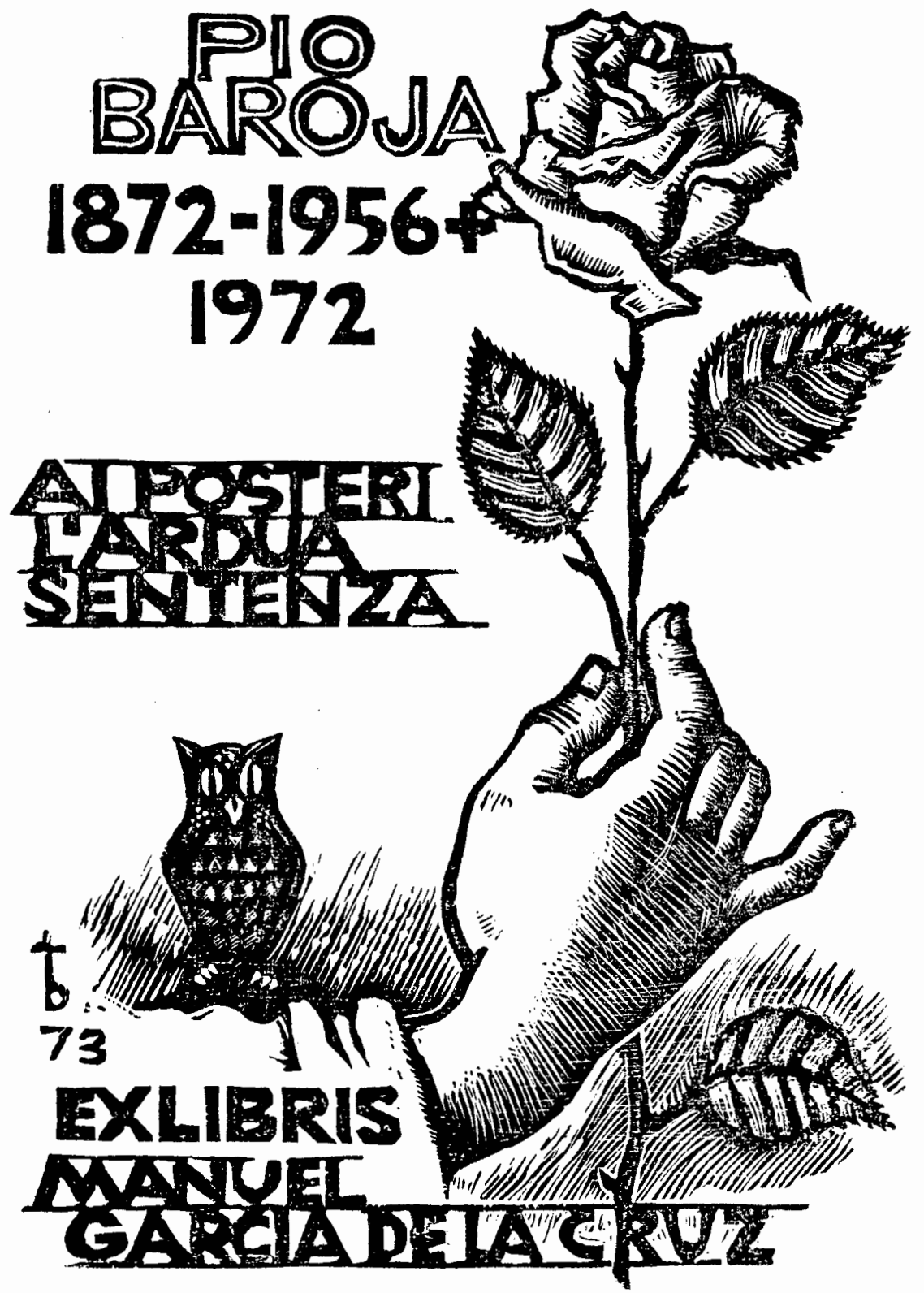